\title{
Väike-Abhaasia suured piiriküsimused
}

\section{Baltisaksa maadeuurijate panus etnilisse argumentatsiooni}

\author{
Aivar Jürgenson \\ Tallinna Ülikooli Humanitaarteaduste instituudi ajaloo, arheoloogia \\ ja kunstiajaloo keskuse vanemteadur \\ aivarj@tlu.ee
}

\begin{abstract}
Teesid: Tänapäeval elab rõhuv enamik Abhaasia eestlastest selle loodeosa kahes külas Salmes ja Sulevis. Piirkonna ajalooline nimetus on Džigetia, seda on nimetatud ka Väike-Abhaasiaks. Ajalooliselt ja etniliselt spetsiifilise Abhaasia regiooni eripärad põhjustavad tänasel päeval Abhaasia piirivaidlusi Venemaaga. Teemal on aga ka baltisaksa mõõde - 19. sajandi saksa, aga eelkõige baltisaksa uurijate tekste saab kasutada ja ka kasutatakse probleemidele lahenduste otsimisel. Artiklis antakse ülevaade 18. sajandi teise poole ja 19. sajandi alguse (balti-) saksa uurimisreisidest Kaukaasiasse, keskendudes eriti neile, mis puudutasid Loode-Kaukaasiat.
\end{abstract}

Märksõnad: Abhaasia, baltisaksa maadeuurijad, Kaukaasia sõda, kolonisatsioon, piirivaidlused

\section{Sissejuhatus}

Kui eesti külad 1880. aastatel Abhaasiasse rajati, polnud Abhaasiat poliitilise ega administratiivse üksusena olemas. Suhhumi ümbruse eesti külad Alam-ja Ülem-Linda ning Estonia kuulusid Kutaisi kubermangu, Psou jõgikonda rajatud Salme ja Sulevi aga Musta mere kubermangu. Piiri kahe kubermangu vahel nihutati mitmeid kordi, kuid tsaarivõimu kokkuvarisemise ajal 1917. aastal paiknes see Bzõbi jõel. Piir mõjutas ka eesti asunike kujunevat paikkondlikku identiteeti. Kuna Abhaasiat administratiivse üksusena ei eksisteerinud, ei tekkinud niipea ka mõistet "Abhaasia eestlased"1. Abhaasia lõunapoolsete eesti asunduste elanikke Kutaisi kubermangu Suhhumi ringkonnas kutsuti "Suhhumi eestlasteks", põhjapoolsete omasid Musta mere kubermangu Sotši ringkonnas "Sotši eestlasteks" (Wunk 1914: 7). Kui eestlased oleksid Abhaasias kanda kinnitanud 19. sajandi algul, oleks olnud põhjust nimetada Suhhumi eestlasi 
Suur-Abhaasia eestlasteks, Salme ja Sulevi eestlasi aga Väike-Abhaasia eestlasteks. Sest just nii neid piirkondi tollal nimetati. Kuid eestlaste kolonisatsioon 19. sajandi alguse Abhaasias poleks olnud kuidagi võimalik - kolonisatsiooni Musta mere idarannikule organiseeris teatavasti tsaarivõim, seda sai tegema hakata aga alles pärast maa alistamist ja kohalike elanike minemakihutamist.

Pika ja verise Kaukaasia sõja (1817-1864) tagajärjel alistatud Loode-Kaukaasias märgiti maha uued piirid. Vene tsaaririigi territoriaaladministratiivne jaotus ei järginud üldiselt etnilisi piire. Ajutise Valitsuse perioodil loodi küll mõnes piirkonnas, sh Eestis, etnilisel alusel kubermange, kuid mitte kõikjal. Kas piir kahe Musta mere äärse kubermangu vahel Bzõbi jõel järgis etnilisi piire?

Küsimuse saab esitada ka teravamas toonis: kas piirkond Bzõbi jõest loodes on Abhaasia või mitte? See on olnud vaidluste teemaks julgelt üle saja aasta ja kipub taas üles kerkima ka tänasel päeval. Kui viimastel kümnenditel on läänemaailm harjunud teadvustama Gruusia ja Venemaa vastasseisus Abhaasiat venemeelse puhvrina, siis artiklis tuuakse esile tänapäevased Venemaa ja Abhaasia vahelised pinged piiriküsimustes. Näidatakse, millist rolli mängib piiritemaatikas etniline argument. Huvitaval kombel kasutavad nii vene kui ka abhaasia autorid oma argumentatsioonis 18. ja 19. sajandi reisimeeste, maadeuurijate ja sõjaväelaste kirjutisi, mille autorid on olnud enamasti baltisakslased. Varasemaid allikaid tuleb abiks võtta sel lihtsalt põhjusel, et 1860. aastatel saadeti piirkonna elanikkond in corpore maalt välja. Maale ei jäänud kedagi, kellelt küsida nende etnilise kuuluvuse kohta. Käesoleva artikli eesmärk on näidata etniliste ja poliitiliste piiride kujunemist ja tähendust Abhaasia loodeosas. Antakse ülevaade 18. ja 19. sajandi uurimisreisidest piirkonda ja näidatakse, kuidas tollased uurimisandmed on emotsionaalsete diskussioonide objektiks ka tänapäeval.

\section{Abhaasia loodepiirist kuni 19. sajandini}

Abhaasia kuningriik laienes 8.-10. sajandini, st pärast Bütsantsi võimuperioodi lõppu, põhjas Kubanimaale. 11. sajandist kuni 13. sajandi esimese pooleni oli mõnede autorite väitel Abhaasia kuningriigi (mis tegelikult oli ühisriik idapoolse Gruusiaga, ametliku nimega Abhaaside ja Kartveelide Kuningriik), põhjapiiriks Kubani jõgi (Kvartšija 2019b: 395). 1240. aastal vallutasid kuningriigi mongolid, mis tõi kaasa ühtse riigi lagunemise. Järgnenud sajanditel, mil piirkonnas võimutsesid esmalt Kuldhord, seejärel merelt Abhaasiasse imbunud genualastest kolonisaatorid ja teatud perioodidel ka naaberriigi Mingreelia vürstid, nõrgenes Abhaasia keskvõim, mistõttu õnnestus riigi põhjapoolsetel 
hõimudel saavutada sõltumatus (Inal-ipa 1995: 19). Teisalt kasutasid Abhaasia nõrkust ära ka põhja poolt peale suruvad adõgee hõimud, hõivates abhaasidega asustatud territooriume ja assimileerides seniseid asukaid (Tšatšhalia 2012: 98). Etniliste abhaaside asuala võis aga ka edaspidi ulatuda tänasest Abhaasia Vabariigi põhjapiirist palju kaugemale põhja poole.

Abhaaside ajaloolise etnilise piiri määratlemine pole lihtne. Näiteks kui tänapäeva autorid viitavad 16. sajandi saksa diplomaadile ja reisimehele Siegmund (Sigismund) von Herbersteinile, kes kirjutas, et Kubani jõe ääres elab rahvas nimega "aphgasi” (nt Tšatšhalia 2012: 98), siis ei tea me tegelikult, kas ta pidas silmas tänapäeva mõistes abhaase või laiemalt abhaasi-adõgee rahvaid. Või hoopis muistse Abhaasia kuningriigi järglasrahvaid. On kirjutatud, et etniliste abhaasidega asustatud territoorium ulatus veel vähemalt 17. sajandi esimesel veerandil Kodoši neemeni Tuapse lähistel (Argun 2012: 13), seega umbes $150 \mathrm{~km}$ tänasest Abhaasia-Vene piirist põhja poole. Rääkides abhaaside põhjapoolsest asualast, osundavad mõned autorid ka itaalia reisimehele Minai Medicile, kes veel 19. sajandi algul märkis üles abhaasi keele näiteid Anapa piirkonnas (Tšatšhalia 2012: 98), seega umbes $360 \mathrm{~km}$ tänasest Abhaasia-Vene piirist loode pool. Pole võimatu, et seal võis tollal olla abhaasi keele rääkijaid, võib-olla ka mõni abhaasi asula. Üksikuid abhaasi asulaid on paiknenud viimastel sajanditel küll kuni Sotši jõeni ja võimalik, et ka kaugemale põhja poole, nagu väidavad tänased abhaasi autorid (Tširikba 2012: 22), kuid täpset etnilist piiri on tänapäeval võimatu fikseerida. 18. ja 19. sajandi autorite kasutatud etnonüümid $a b a z a$, abasa või $a b a z i$ võisid tähendada ka näiteks ubõhhe, kes on siirdeetnos abhaaside ja adõgeede vahel ja kes elasid 19. sajandil enne väljasaatmisi kahe jõe - Sotši (Sotšapsta) ja Šakbe -vahelisel alal. Kabardid on lugenud abazade hulka ka näiteks šapsuge, nimetades neid abadze-thil (tõlge: abazi rahvad) (Kvartšija 2019b: 402, vt ka Richmond 2008: 18). Üldtunnustatult loetakse šapsuge adõgee etniliseks rühmaks. Kui mõned autorid on laiendanud abhaaside asuala kaugemale kui see tegelikult oli, tuleneb see ilmselt terminoloogilisest segadusest.

Kui 18. ja 19. sajandi kaartidel tähistatakse Musta mere rannikuala toponüümiga Abaza, siis võib see tähistada hoopis suuremat ala kui tänane Abhaasia Vabariik või 19. sajandi alguse Abhaasia vürstiriik. Kohati eristatakse SuurAbazat (pr Grande Abaza, sks Grosse Abaza, vn Boljšaja Abaza) Väike-Abazast (pr Petite Abaza, sks Kleine Abaza, vn Malaja Abaza): enamasti mõistetakse esimese all piirkonda Inguri jõest lõunas kuni Kubani jõeni põhjas, teine tähistab piirkonda tänapäeva Karatšai-Tšerkessias (Kvartšija 2019a: 222; 2019b: 404). Abaza oli seega termin, mis tähistas laiemalt abhaasi-adõgee rahvaste asuala ja kattis suures ulatuses muistse Abhaasi kuningriigi territooriumit. 


\section{Suur- ja Väike-Abhaasia}

19. sajandi venekeelsetes allikates üldiselt eristatakse termineid Абаза ja Абхазия - viimane tähistab Abhaasia vürstiriiki selle poliitilistes piirides ja

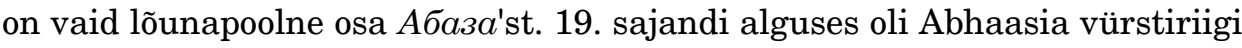
piiriks lõunas Inguri jõgi, sinna olid Abhaasia vürstid selle nihutanud sõdades Mingreelia vürstiriigiga 17. sajandil. Loodes/põhjas paiknes Abhaasia vürstiriigi piir 19. sajandi alguses Bzõbi jõel, seega sadu kilomeetreid lõuna pool keskaegsest Abhaasia kuningriigi piirist ja umbes $35 \mathrm{~km}$ lõuna pool tänasest Abhaasia-Venemaa piirist. Abhaasia vürstiriiki nimetati ka Suur-Abhaasiaks. Territooriumi, mis jääb tollasest Abhaasia vürstiriigist põhja poole, lõunapiiriga Bzõbi jõel ja põhjapiiriga Sotšapsta (Sotši) jõel, nimetati Väike-Abhaasiaks (Atšugba 2012: 7; Inal-ipa 1995: 55). ${ }^{2}$ Väike-Abhaasia oli asustatud sadzi ehk džigeti etnilise rühmaga (abhaasi keeles: $a$-cázyaa). Džigetid on eksonüüm, sadzidele kinnistunud gruusia ja vene allikate vahendusel (Inal-ipa 1995: 13). ${ }^{3}$ Seda asustanud rahva järgi nimetati Väike-Abhaasiat ka Sadzeniks, Sadzi Abhaasiaks või Džigetiaks (Atšugba 2012: 7; Inal-ipa 1995: 55; Bodenstedt 1849: $169,170)$. Siinses artiklis eelistatakse toponüümi Džigetia, mida kasutatakse teaduskirjanduses teistest laialdasemalt.

Kes olid sadzid/džigetid? Kuna nad asustasid piirkonda, kuhu hiljem rajasid oma asundused ka eestlased, ja kuna ka tänastes piiridispuutides mängivad nad olulist rolli, olgu siinkohal esitatud väike ülevaade nende paiknemisest.

Sadzid jagunesid kogukondadeks, kellest 19. sajandi esimesel poolel, st enne venelaste vallutusi, oli võimsaim tsandripši kogukond asualaga Bzõbi ja Tsandripši ehk Hašupse jõgede vahel, kogukonna keskus oli Hašupsi kindlus. Kogukond sai nime Tsanba nime kandva vürstisoo järgi. Hašupse jõest Mzõmta jõeni laiusid getši kogukonna (vürst Getšba järgi) asualad. Just sellesse piirkonda tekkisid hiljem eestlaste külad Salme ja Sulevi ning rida teisi 19. sajandi kolonistide külasid. Enne seda olid Psou jõe orus getši džigettide külad Pathurha, Bagripš, Mikelripš, Kudžripš jt (Atšugba 2012: 9). Abhaasia autorid on välja toonud, et kuigi eestlaste rajatud Salme nimi on küll eestikeelne, kõlab see huvitaval kombel väga sarnaselt sadzi vürsti Salama nimega, kes valitses selles piirkonnas kuni väljasaatmisteni (Kvartšija 2019a: 78).

Tänapäeval Vene Föderatsiooni Krasnodari krais asuv Adleri linn sai laialt levinud rahvaetümoloogia järgi nime saksa sõnast Adler (sks Adler - kotkas). Tegelikult asustas seda piirkonda sadzide ardi kogukond (vürst Ardba järgi). Türklased nimetasid nende maade elanikkonda ardler (Atšugba 2012: 10). Veel 1840. aastatel kasutati selle koha puhul nimevarianti Ardiller (Bodenstedt 1849: 194). Hašupse jõe ülemjooksul, Tšandripšist kõrgemal mägedes paiknes 
väike hõša kogukond. Oli ka teisi väiksemaid sadzi/džigeti kogukondi, kuid neil pole põhjust siin peatuda.

Kõrgemal mägedes paiknesid sadzidele lähedased abhaasi kogukonnad, keda ei loeta sadzide/džigettide hulka kuuluvaiks: Hašupse ja Psou jõgede ülemjooksul Hõšast kõrgemal mägedes elunes aibga (айььб̨̧) kogukond. Sellest piirkonnast tuleb edaspidi juttu ka seoses eesti asunikega. Mzõmta ülemjooksul kuni lumiste mägedeni asusid ahtšipsõ ( $a x y b$ ınçbí) abhaasi kogukonna maa-alad, millel oli strateegiliselt oluline positsioon - sealt läks ühendustee läbi mäekuru ubõhhide ja edasi adõgeede asualadeni (Atšugba 2012: 10). Just nende maa-aladel paikneb tänapäeva Vene Föderatsiooni Krasnodari kraisse jääv Krasnaja Poljana ning eestlaste asundus Eesti Aiake.

Gruusia kroonikate andmeil oli Džigetia 15.-18. sajandini mitte üksnes etniline, vaid ka poliitiline mõiste - piirkond sõltus Abhaasiast, oli aegajalt selle osa, aegajalt aga iseseisev. Sagedased olid omavahelised trooniabielud, ühiselt võeti ette sõjaretki Guria ja Mingreelia vürstiriikide vastu. 16. sajandi keskel langes Džigetia (nagu ka ülejäänud Abhaasia) Türgi sultani võimu alla, mis tõi kaasa islamiseerumise, vähemalt ülikkonna seas ja ilmselt eelkõige merkantiilsetel eesmärkidel (Inal-ipa 1995: 24-25). Türgi ja Venemaa tegevus 19. sajandi algul nõrgestas Abhaasia võimu, kuid ka sel ajal oli Džigetia vähemalt nominaalselt sõltuv Abhaasia vürstist. Pärast 1810. aastat, mil Abhaasia vürstiriik muudeti Venemaa protektoraadiks, keeldusid džigetid Venemaale allumast. Kuni 1830. aastateni korraldasid džigetid ja mägedes elavad abhaasid korduvalt sõjaretki Abhaasia vürstiriigi territooriumile, mida mõned autorid tõlgendavad Abhaasia kodusõjana (Tšatšhalia 2012: 100; Kvartšija 2019b: 405). 1840. aastate algul sunniti džigetid alistuma ja nende territooriumil moodustati eraldi pristavipiirkond (приставство) Kutaisi kubermangu koosseisus. Seejärel liideti pristavipiirkond Abhaasia vürstiriigiga (Tšatšhalia 2012: 101), ilmselt tänutäheks kollaboratsionistist Abhaasia vürsti Mihhail Šervašidze panusele džigettide alistamisel. Nii nihkus Abhaasia vürstiriigi piir loodes Mzõmta jõeni. Kuid juba 1847. aastal eraldati vürstiriigist loodepiirkond Bagripsta (Holodnaja) jõest Mzõmta jõeni, seega umbes pool Džigetiast, ja liideti Musta mere kubermanguga (Kvartšija 2019b: 405; Kvartšija 2019a: 34).

Kaukaasia sõja lõpufaasis ja pärast seda saadeti džigetid 1860. aastatel koos ubõhhide ja põhja pool elavate adõgee etniliste rühmadega oma asupaikadest välja. Piirkond tühjendati elanikkonnast. Arseni Vereštšagin, Musta mere ranniku koloniseerimise peamine ideoloog, kirjutas pärast seda, kui oli 1870. ja 1873. aastal teinud ringreisi Musta mere ringkonnas: "Ei Psou ega Mzõmta jõgikonnas ole juba hulk aastaid mingit elumärki” (Vereštšagin 1874: 66). Etniline puhastus lõi soodsa pinnase hilisemaks eestlaste jt kolonisatsiooniks, kuid 
seab meid täna probleemi ette: kes olid džigetid? Küsimus pole huvipakkuv mitte üksnes ajaloolis-etnograafiliselt, vaid ka poliitiliselt: džigettide etniline kuuluvus annab tublisti sümboolset kapitali Vene-Abhaasia piiri üle peetavateks diskussioonideks. Tänapäeval jookseb Abhaasia-Venemaa piir teatavasti mööda Psou jõge, st suurem osa Džigetiast kuulub Abhaasiale.

Abhaasi autorite üldisel hinnangul olid džigetid abhaaside etniline grupp (Inal-ipa 1995: 49, 175; Atšugba 2012: 7-9; Tširikba 2012: 22), mis tähendab, et Abhaasia tänane etniline ja poliitiline piir suures osas kattuvad. Kui aga tegemist ei oleks etniliste abhaasidega, annaks see naaberriigile Venemaale sümboolset kapitali diskussiooniks tänase Abhaasia loodepiiri üle. Seetõttu ei maksa imestada, et just Vene autorid üritavad seada kahtluse alla džigettide kuulumist abhaaside hulka. Juba Nõukogude ajal nimetas Natalja Volkova džigette "lõuna-abasiinideks" (Volkova 1974: 65, 74), seega mitte-abhaasideks. Selge etnilise piiri abhaaside ja džigettide vahele tõmbab Ekaterina Arhipova (2014: 45, 72), väites varjamatult, et Abhaasia vürstiriigi piir Bzõbi jõel järgis etnilist piiri (Arhipova 2014: 59). Küsimus ei ole üksnes teaduslik või hüpoteetiline. Kui 2010. aastal moodustati Vene Föderatsiooni ja Abhaasia Vabariigi komisjonid kahe riigi omavahelise piiri fikseerimiseks, esitas Vene pool abhaasidele territoriaalseid pretensioone just vaatlusalusel territooriumil, tänapäeva Abhaasia Gagra rajooni aladel (Kvartšija 2019a: 239-240). Kuna džigetid küüditati 1860. aastate esimesel poolel, pole piirkonnas enam kedagi, kellelt nende kuuluvuse kohta küsida. Tugineda saab siin varasematele, 18. ja 19. sajandi esimese poole autoritele, peamiselt saksa/baltisaksa maadeuurijatele ja sõjaväelastele.

\section{Esimesed (balti)saksa maadeuurijate reisid Loode-Kaukaasias}

Varasemate sajandite kohta puuduvad allikad, mis kirjeldaksid täpselt LoodeKaukaasia etnosi, nende paiknemist ja omavahelisi piire. Isegi veel 18. ja 19. sajandi kartograafiliste kirjelduste autorid ei suutnud eristada erinevaid abhaasiadõgee rahvaid, nimetades neid koondnimetusega kas tšerkessideks (Atšugba 2012: 7) või abasadeks/abazadeks. Autorid, kes küll eristasid erinevaid rahvaid, kasutasid üksteisega vastuollu minevaid klassifikatsioone, need ei suutnud määratleda etnilisi ega hõimupiire. Kui lugeda 19. sajandi kirjutisi, kohtab seal sageli kurtmist Kaukaasia rahvaste segase paiknemise üle. 1840. aastatel Musta mere idarannikul rännanud Hannoverist pärit saksa õpetlane Friedrich Martin von Bodenstedt kaebas, et Kaukaasia rahvaste asualade ja nende dialektide piiritlemine on äärmiselt keeruline (Bodenstedt 1849: 186). 
Bodenstedti kurtmine oli põhjendatud: 18. sajandi lõpus ja 19. sajandi algul oli ilmunud mitmeid teoseid, mis andsid ülevaate Kaukaasia rahvastest, kuid tulemused olid võrdlemisi erinevad.

Esimeseks olulisemaks Kaukaasia maa ja rahvaste kirjelduseks oli Johann Anton Güldenstädti teos "Reisen durch Rußland und im Caucasischen Gebürge", mille esimene osa ilmus Peterburis 1787. aastal. Güldenstädt oli sündinud 1745. aastal Riias sealse Ülemkonsistooriumi sekretäri ja hilisema ülemkohtu assessori Anton Güldenstädti pojana. Tema ema Dorothea oli Pärnu linnapea Jacob von Virgini tütar. Johann Anton jäi varakult orvuks: 1758. aastal suri tema isa, kolm aastat hiljem, 1761. aastal ka ema. 1763. aastal asus ta oppima Berliini meditsiinikolleegiumis ja omandas 1767. aastal 22aastaselt doktorikraadi (Pallas 1787: VII). Samal aastal organiseeriti Peterburi Teaduste Akadeemia kompleksekspeditsioon, mastaapne ettevõtmine, mis viis palju nimekaid teadlasi riigi erinevatesse piirkondadesse ja selle lähinaabrusse, ning kestis aastani 1774. Ekspeditsiooni üks initsiaatoritest oli keisrinna Katariina II, kes vajas tuge oma reformipüüdlustele ja soovis näidata end maailmale valgustatud monarhina. Ekspeditsioon jagunes kolmeks - Orenburgi, Astrahani ja astronoomiliseks ekspeditsiooniks (Schüler \& Rohlfing 1998: 67). Esialgselt pidi Güldenstädt uurima Astrahani kubermangu, kuid plaanid muutusid ning tema ülesandeks sai reisida Kaukaasiasse. 1770. aasta jaanuaris jõudis Güldenstädt Tereki jõe äärde Põhja-Kaukaasias, sealt liikus ta edasi Kaukasuse idaossa ning 1771. aasta kevadel Osseetiasse. Suve veetis ta Kabardas, septembris ületas Kaukasuse peaaheliku ja jõudis tänapäeva mõistes Gruusiasse. Tema saatjas- ja vastuvõtjaskond sel reisil oli muljetavaldav: nii Kaheetias kui ka Imereetias saatis Güldenstädti ringreisil kohalik vürst. 1773. aasta suvel reisis ta taas Kabardas ühe kohaliku üliku saatel (Pallas 1787: VIII-X). Reis oli pikk - alles 1775. aastal jõudis Güldenstädt tagasi Peterburgi, kus ta oli vahepeal nimetatud sealse Teaduste Akadeemia liikmeks ja loodusteaduse professoriks. Järgnenud aastad kulusid kirjatööle ja praktiseerimisele arstina (Pallas 1787: X-XV).

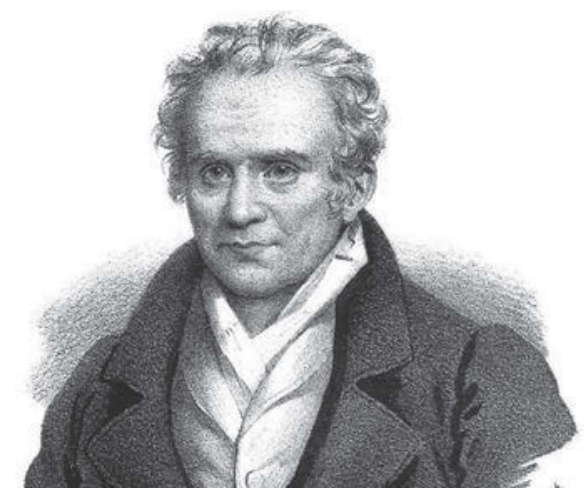


Peterburi Teaduste Akadeemia oli asutatud teatavasti 1724. aastal ning õige pea alustati suurejooneliste uurimisekspeditsioonidega riigi erinevatesse piirkondadesse. Kui esimeste ekspeditsioonide tulemusi varjati strateegilistel põhjustel kiivalt ning uurijatel keelati oma uurimistööde tulemusi avaldada, siis sajandi teisel poolel muutus olukord vastupidiseks. Nüüd hoolitseti selle eest, et ekspeditsioonide materjalid võimalikult kiiresti avalikkuse ette jõuaksid. Selle põhjuseks on peetud Katariina II soovi paista välja teaduse soosijana. Ekspeditsioonide tulemuste põhjal valminud publikatsioonid anti välja paljudes keeltes ja neid levitati Euroopas laialdaselt. Güldenstädti uurimisreisi tulemused küll viibisid ja lõpuks ei lasknud põdur tervis tal oma ekspeditsiooni tulemuste ilmumist näha - ta suri 1781. aastal vaid 36aastasena. Tema teose andis kuus aastat hiljem välja Peter Simon Pallas (Pallas 1787: XV), Peterburi Teaduste Akadeemia liige ja tollesama kompleksekspeditsiooni Orenburgi uurimisreisi juht.

Güldenstädt kirjeldab oma raamatus paljusid Kaukaasia rahvaid, ka neid, kelle asualadele ta ise ei jõudnud. Viimaste hulka kuuluvad ka abhaasid ja džigetid, kelle kohta sai ta informatsiooni ilmselt Mingreelias reisides. Güldenstädti tekst, mis puudutab Abhaasiat, on võrdlemisi segane ja annab tunnistust sellest, et põhjalikke teadmisi ta piirkonna kohta ei omandanud. Ta kasutab Mingreeliast põhjas asuva piirkonna kohta kaht erinevat terminit - Abchas ning Abchasia. Abchas piirneb tal lõunas Inguri (Enguri) jõega ja põhjas Kubani jõega (Güldenstädt 1787: 465). Sellest võib teha järelduse, et Abchasi all mõtles Güldenstädt laiemalt abhaasi-adõgee rahvaste asuala. Seda kinnitab ka tõik, et ta loeb piirkonna elanike abazide hulka ka ubõhhid. Oluline on Güldenstädti märge, kus ta Abchasia elanikena nimetab ka sadze (Güldenstädt 1787: 465). 19. sajandi alguse vene autor Semjon Bro-

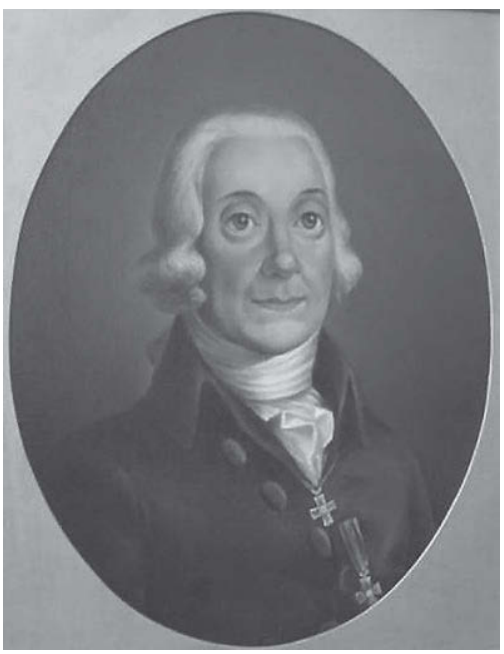
nevski kirjutas maast nimega Abazgia, mis paikneb 300 versta ulatuses Musta mere rannikul - alates Sudžuk-Kale kindlusest kuni Inguri (Enguri) jõeni (Argun 2012: 13). Seega põhja suunas taas hoopis suurem piirkond kui Abhaasia vürstiriik. Pole võimatu, et Bronevski tugines samuti Güldenstädtile. 
Seoses Güldenstädti raamatu väljaandmisega nimetatud Peter Simon Pallas avaldas hiljem aga ka enda reisimärkmetele tugineva teose (Pallas 1803), mis keskendus tsaaririigi lõunapoolsetele piirkondadele. 1741. aastal Berliinis sündinud Pallas oli bioloog ja kaitsnud 1760. aastal parasitoloogiaalase doktoritöö Leidenis. Temast pidanuks saama arst, kuid siis lõppes Seitsmeaastane sõda, kuhu ta soovis arstina siirduda. Saksamaal ega Hollandis ta tööd ei leidnud ning 1767. aastal sõitis ta koos abikaasaga Peterburgi, kus temast sai peagi Peterburi Teaduste Akadeemia loodusteaduste professor (Wendland 1986: 8-9).

Kaukaasia puhul piirdub Pallase raamat märkmetega põhja pool SuurKaukasust elavate rahvaste kohta, kes ühel või teisel perioodil on Vene tsaari võimu tunnistanud. Pallas toetub omaenda nähtule, aga ka teiste reisimeeste kirjeldustele. Ta tunnistab Güldenstädti küll esimeseks autoriks, kes võttis vaevaks kirjeldada ja süstematiseerida Kaukaasia rahvaid, kuid ei jäta teda ka kritiseerimata: Güldenstädti teated nende rahvaste eluolu ja kommete kohta on Pallase sõnul väga puudulikud (Pallas 1803: 327). Tõsi ta ju on, kuid kui lugeda Pallase enda kirjeldusi, ilmneb, et need pole sugugi põhjalikumad. Ta piirdub märkmetega peamiselt Kubanimaa rahvastest. Tollele ajale iseloomulikult nimetab ta piirkonda Abasaks, eristades Suur- ja Väike-Abasat (Kleine und Grosse Abasa). Väikest Abasat piiritleb ta idas Kubani jõe lätetega ja läänes Musta merega. Piirkonna elanikud, keda ta nimetab Abassen (Pallas 1803: 328, 329), on tal nähtavasti mitte etnonüüm, vaid koondtermin. Abasasid eristab Pallas abassiinidest (Abassiner) - need kaks rahvast sõdivad tema sõnul alatasa omavahel (Pallas 1803: 329). Pallase kasutatud "Abassiner" ei ole kindlasti sama tänapäeva abasiinidega, vaid pigem samuti koondtermin erinevate rahvaste tähistamiseks: ta kasutab seda mõistet nii Põhja-Kaukaasia elanike kui teisel pool Kaukasuse ahelikke elavate hõimude tähistamiseks. Viimased paigutab ta Suhhumi (Pallasel: Dioskurias) piirkonda (Pallas 1803: 335), mistõttu on need järelikult identifitseeritavad abhaasidena.

Suur-Abasat Pallas ei piiritle, kuid loetleb seal elavaid rahvaid, teiste seas ubõhhe ja šapsuge (Pallas 1803: 332), mainides samuti, et Suur-Abasa ulatub teisele poole Kaukasuse ahelikke (Pallas 1803: 335), seega tänapäeva Abhaasiasse. Rahvaid kirjeldades on Pallas selgelt tollaste stereotüüpide kütkes. Üks Urupi jõe ääres Põhja-Kaukaasias elav Suur-Abasa piiresse kuuluv rahvarühm (Beschilbai) pälvib Pallaselt lühikese iseloomustuse: nad elavad vaeselt ja on "sarnaselt kõikide oma naabritega suured röövlid" (Pallas 1803: 331). "Abassiinide" kohta teatab Pallas, et nad olevat juba muistsest ajast olnud röövihimuline rahvas. Edasi kirjutab ta "tšerkesside sõjakast rahvast", kes on oma valdustest senised elanikud minema ajanud ja suure osa rahvast oma alamateks teinud. Siis aga võrdleb ta tšerkesse saksa rüütlitega, kes Preisi- ja Liivimaal veel suurema ebainimlikkusega silma paistsid (Pallas 1803: 335). Edasi nimetab Pallas 
tšerkesse ilusamateks teistest tema poolt nähtud "harimata rahvastest" (Pallas 1803: 342) - niisiis on kohalikud rahvad sõjakad ja harimatud, kuigi mõned võivad olla ilusad. Pallase teose selles osas, mis puudutab Loode-Kaukaasia rahvaid, valitseb lisaks stereotüpiseerimisele suur terminoloogiline segadus. Erinevaid piirkonna etnoseid ta - mõned erandid välja arvatud - geograafiliselt ei määratle, ta kasutab üldtermineid läbisegi konkreetsemate etnonüümidega ja on mitmes muuski mõttes pealiskaudsem kui näiteks tema poolt kritiseeritud Güldenstädt. Meid huvitavat Džigetiat ehk Väike-Abhaasiat ta ei mainigi. Juttu on küll Väike-Abasast, kuid nagu teame, oli see midagi muud.

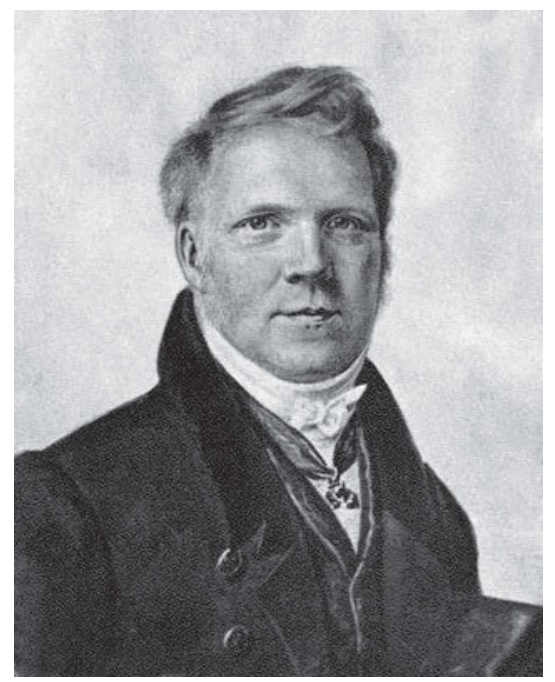

Otto Moritz Ludwig von Engelhardt (geni.com).

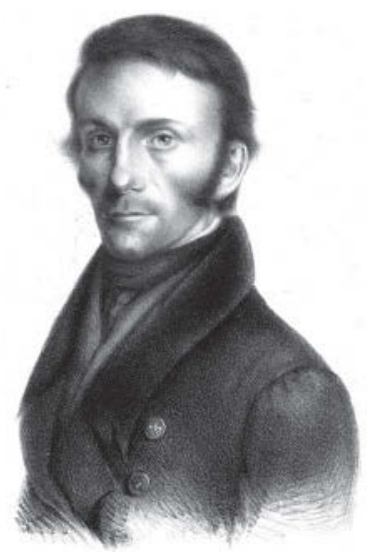

Johann Jacob Friedrich Wilhelm Parrot (en.vikipedia.org).

1811. aastal siirdusid Kaukaasiasse uurimisreisile kaks Eesti taustaga meest. Üks neist, Otto Moritz Ludwig von Engelhardt, sündinud Järvamaal Viisu mõisas 1779. aastal tulevase Eestimaa rüütelkonna peamehe ja maanõuniku Gustav Friedrich von Engelhardti pojana, oli õppinud Tallinna Toomkoolis, hiljem isa soovil Leipzigis ja Göttingenis õigusteadust, kuigi juba varasemast ajast oli tal kirg pigem loodusteaduste vastu. 1800. aastal esindas ta Eestimaa aadlit Balti provintsidesse ülikooli rajamise komisjonis. Seejärel õppis ta Freiburgi Mäeakadeemias (Kruusmaa 2020: 5). Hiljem töötas ta Tartu Ülikoolis mineroloogiaprofessorina. Teine ekspeditsiooni liige, Johann Jacob Friedrich Wilhelm Parrot, oli sündinud (1791) Karlsruhes Saksamaal, kuid õppinud Tartu Ülikoolis, kus tema isa oli rektor. Hiljem sai Johann Jacob Friedrich Wilhelm Parrot tuntuks Ararati mäe tipus käimisega, mis on ka Eestis suurt tähelapanu pälvinud. Engelhardti ja Parroti ühise reisi eesmärgid olid peamiselt loodusteaduslikud, kuid nende hiljem avaldatud teoses sisaldub ka andmeid kohalike elanike, eelkõige vene kasakate kohta. Kui 
Güldenstädt sai kasutada kohalike vürstide saatjaskondi, siis Engelhardt ja Parrot liikusid peamiselt mööda Kaukaasia liini kasakajaamu (staniitsasid) ja kasutasid liikumisel julgestuseks konvoisid, mistõttu nende kirjeldused põliselanikest on juhuslikumat laadi ja napimad (nt Engelhardt \& Parrot 1815: 128) kui Güldenstädtil.

Tegelikult toimus enne Engelhardti ja Parroti reisi veel üks uurimisreis Kaukaasiasse, kuid selle tulemused ilmusid trükis pärast tartlaste reisi. Nimelt viibis ajavahemikus 1807-1809 Kaukaasias orientalist Heinrich Klaproth, kes oli saanud hariduse Halle Ülikoolis ja tegutsenud Berliinis, Weimaris ja Dresdenis. Tema Kaukaasia-ekspeditsioon toimus Peterburi Teaduste Akadeemia ülesandel ja viis teda 1807. aasta septembris Moskva ja Harkovi kaudu Tšerkasskisse, sealt Georgievskisse, tollasesse Kaukaasia kubermangu keskusesse, kus ta kogus andmeid tšerkesside kohta. Seejärel suundus ta Mosdokki, kogudes infot osseetide ja kistide kohta. Järgnes ringreis Kabardas ja Tereki jõe ääres, kust ta suundus tänapäeva mõistes Gruusiasse. Tiflissi jõudis Klaproth 1808. aasta jaanuaris. Gruusias reisis ta mööda Kahheetiat, st Ida-Gruusiat, ja jõudis ka lesgiinide aladele tänapäeva Aserbaidžaanis. Lääne-Gruusiasse ega Abhaasiasse Klaproth igatahes ei sattunud. Mägedes jõudis ta Tereki jõe lätete juurde ja õiendab sellega seoses oma teoses arveid Engelhardti ja Parrotiga väites, et just temale kuulub au Tereki lätete avastamise eest ja mitte neile Tartu tudengitele (Dorpatsche Studirende) (Klaproth 1812: VI-VII).

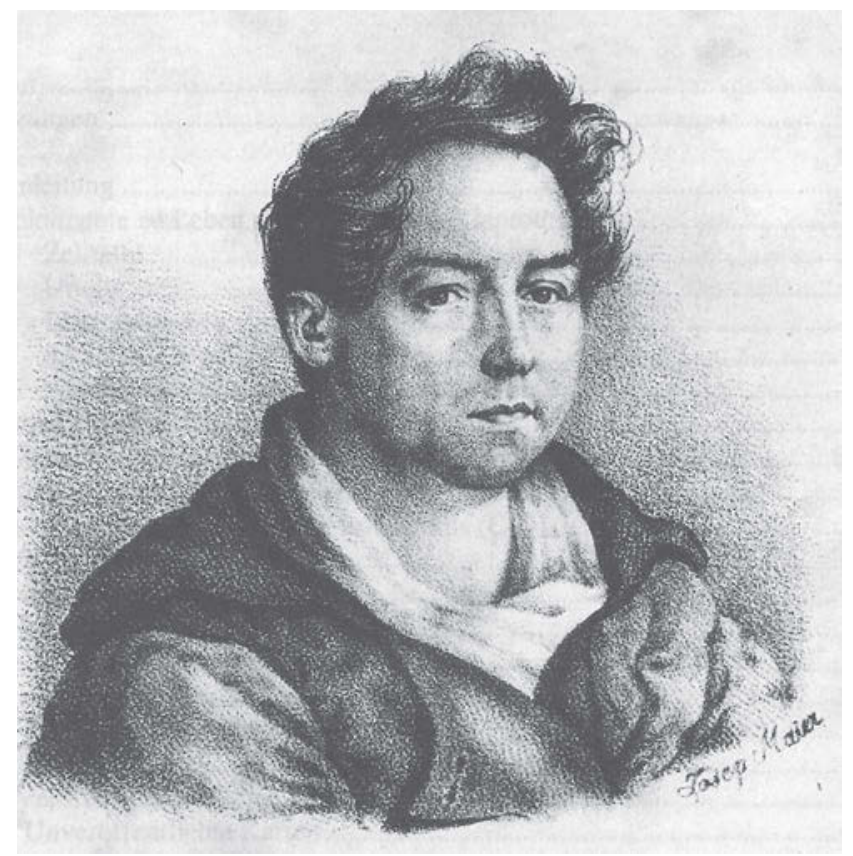


Nagu teame, ilmus Klaprothi teos pärast Tartu tudengite reisi, nii et viimased reisil olles Klaprothi avastustest teadlikud olla ei saanudki. Tagasi Peterburgi jõudis Klaproth plaanitust varem 1809. aasta jaanuaris - Teaduste Akadeemia kutsus ta tagasi, keelates ka reisikirja ja reisitulemuste avaldamise. Selle asjaolud on ebaselged, võimaliku põhjusena on pakutud Kaukaasia koloniaalsuhete liiga avameelset käsitlemist (vt Kruusmaa 2020: 21). Igatahes lahkus Klaproth teenistusest ja läks Saksamaale, kus ta oma kaheköitelise teose (Klaproth 1812,1814) ka avaldas. Teose eessõnas põhjendab ta avaldamist Saksamaal sellega, et Venemaal välja antud teosed ei jõua laiema lugejaskonnani (Klaproth 1812: V). Võimalik, et see polnud päris siiras põhjendus.

Klaprothi teos on tollasest mõõdupuust lähtudes põhjalik. Ta kirjeldab nähtud rahvaste tavasid, religiooni, aga ka materiaalset kultuuri ja esitab rohkesti keelenäiteid. Kuid nagu öeldud, meid huvitavasse Loode-Kaukaasiasse ta ei jõudnud, kuigi kirjeldab ka seal elavaid hõime. Kellele ta seejuures tugineb? Kontekstist nähtub, et ilmselt eelkõige reisil kohatud venelastele ja grusiinidele. Ta teab, kuidas venelased Kubani jõe taga elavaid rahvaid nimetavad, ta leiab, et nii venelastele kui mingreelidele oleks kasulik hallata (koloniseerida?) Musta mere rannikupiirkonda Poti ja Anapa vahel (Klaproth 1812: 482), seega vallutada sealsed rahvad. Teatavasti oli Mingreelia 19. sajandi esimeseks kümnendiks allutatud tsaaririigile ja sealt juhiti edaspidi Loode-Kaukaasia vallutamist. Grusiinide näpujälgi on näha Klaprothi väites, et Suhhum, gruusia keeles Tzchomi, on gruusia linn (Klaproth 1812: 478). Kuid Klaproth toetub oma teoses ka seni avaldatud kirjandusele. Näiteks kui ta teatab, et bešilbaid on suured röövlid (Klaproth 1812: 455), siis seda oleme kuulnud juba varem Pallaselt. Suurteks röövliteks nimetab ta ka abhaaside sugulasrahvast ubõhhe, kuid lisab, et nad kasvatavad häid viinamarju (Klaproth 1812: 463). Klaproth jaotab Loode-Kaukaasia rahvad tšerkessideks ja abassideks (Abassen), kirjeldades mõlema kategooria hõime eraldi. Mitmete Kubanimaa abasside kohta teab ta, et nad on suguluses Suhhum-Kale ümbruses elavate abassidega. Viimaste, st abhaaside kohta ta eraldi etnonüümi ei kasuta. Ta mainib vaid, et Suhhumi ümbruse abassidest pisut eemal mägedes elab rahvas nimega Bsubbeh (Klaproth 1812: 478). Ilmselt peab ta silmas abhaasi bzõbi rühma ja mitte nende naabruses elavaid džigette. Kuigi Klaprothi teos on põhjalik Põhja-Kaukaasia keskosa ja Ida-Gruusia osas, siis Loode-Kaukaasia kirjeldamisel toetub ta sekundaarallikatele ja on võrdlemisi pealiskaudne.

Ära võib siinkohal mainida ka Moritz von Kotzebue reisikirja "Teekond Pärsiasse", mis kirjeldab autori reisi Venemaa saatkonna koosseisus Pärsia šahhi juurde 1816. aastal. Teose andis 1819. aastal Weimaris välja tema isa August von Kotzebue, kelle nime teatakse Eestis eelkõige seoses Tallinna teatrieluga ja Eestis kirjutatud romaanide ning näidenditega. Poeg Moritz osales aastail 
1803-1806 koos kaks aastat vanema venna Ottoga Venemaa esimesel ümbermaailmapurjetamisel, mida juhtis Adam Johann von Krusenstern. 1807-1810 tegeles ta Eestimaa kubermangu kaardistamisega, hiljem tegutses selles vallas ka teistes tsaaririigi piirkondades. Ka pärast mainitud Pärsia-reisi jäi ta pikemaks ajaks seotuks Kaukaasiaga. Teostanud mitmel pool Gruusias astronoomilisi mõõtmisi, määrati ta 1822. aastal Kaukaasia Erikorpuse ülemkortermeistriks ja osales 1826. aastal sõjakäigul Pärsiasse (vt Benno 2018: 130-132).

Moritz von Kotzebue "Reis Pärsiasse" kirjeldab teekonda, mis viis läbi PõhjaKaukaasia ja üle Kaukasuse ahelike kõigepealt Tiflissi ja sealt nädal hiljem Pärsiasse. Põhja-Kaukaasias reisiti sarnaselt Engelhardti ja Parroti reisiga läbi kasakajaamade, saatjateks mitu kasakat, keda jaamast jaama vahetati. Kuni Georgievskini sõideti umbes 60 kilomeetrit piki Kuma jõge. Kotzebue kirjutab teisel pool jõge elavatest "armastusväärsetest tšerkessidest, kabardiinidest jne, kes pidevalt tegelevad röövimisega [---] esimesel võimalusel röövivad nad asju ja inimesi ning rüüstavad seal, kus saavad”. Ta kirjutab pikemalt nende veritasukohustusest (nagu ka peaaegu kõik teised Kaukaasia ja selle rahvaste kirjelduste autorid) ja leiab: “Tänatud olgu saatus ja türklased, kes neile tihti katku saadavad, misläbi seda umbrohtu siiski mingil määral välja roogitakse, muidu ei saaks selle rahvaga üldse hakkama." Ta õigustab venelaste sõjaretki, mille käigus nad mägedesse tungivad ja mägilaste maju purustavad ning nende karja ära viivad (Kotzebue 2018: 16-17). Georgievskist Mozdokki liiguti piki Tereki jõge. Kotzebue sõnul (mis muidugi on andmed vene sõjaväelastelt ja kasakatelt) muudavad selle lõigu ohtlikuks kabardid, kes "nimetavad end küll meie sõpradeks, aga ei suuda taltsutada oma röövimiskihku" (Kotzebue 2018: 21).

Edasi ületati Kaukasuse mäestik ja jõuti 10. oktoobril Tiflissi, kuhu jäädi üheks nädalaks. Kuid see oli Kotzebuele ilmselt piisav aeg selleks, et öelda midagi põhjapanevat ka grusiinide kohta. Ja see miski oli, et nad on laisad (Kotzebue 2018: 27, 33). Edasi viis teekond juba Pärsia poole ja kuna LoodeKaukaasia rahvastest tema reisikirjas rohkem juttu ei tehta kui need varem esitatud üksikud põhjapanevad tõdemused tšerkesside kohta, pole siinkohal põhjust tema teosel pikemalt peatuda. Kotzebue paikapanevatest stereotüüpidest nõretav reisikiri sunnib kahvatuma ka Pallase teose vastavad lõigud ja väärib siinkohal mainimist vaid konteksti süvendamise eesmärgil.

Igatahes võib öelda, et kuni Kaukaasia sõja alguseni (1817) jäi riialase Güldenstädti ülevaade peamiseks teaduslikuks tekstiks Kaukaasia loodeosa rahvaste kohta. Siis aga algas sõda, ja kui selle raskuskese kandus 1830. aastate algul Kaukaasia idaosast loodeossa, ei olnud vajadus piirkonda ja seda asustavaid rahvaid tundma õppida ühtäkki enam mitte niivõrd teaduslik, kuivõrd eelkõige sõjalis-strateegiline. 


\section{Parun Theodor von Tornau ja tema luureretked Loode-Kaukaasias}

Esimesed põhjalikumad kartograafilised andmed Loode-Kaukaasia kohta pärinevad baltisaksa (Kuramaa) juurtega keiserliku Venemaa ohvitserilt ja maakuulajalt parun Theodor von (venepäraselt Fjodor Fjodoroviť̌) Tornault (ka Turnau, Tornow). Just temale toetub suurem osa kaasaegsetest autoritest, kes kirjutavad etnilistest ja geograafilistest piiridest abhaaside ja džigettide vahel (näiteks Inal-ipa 1995: 50; Atšugba 2012: 7-9; Argun 2012: 13).

Theodor von Tornau sündis 1810. aastal Kuramaa paruni pojana Polotskis. Tema suguvõsa koosnes suures ulatuses sõjaväelastest: isa oli Vene armee ohvitser, kes Napoleoni vastu peetud sõjas sai 1813. aastal Dresdeni all haavata ja suri, vanaisa teenis Katariina II armees kindralina ja onu feldmarssalina. Theodor sai hariduse Tsarskoje Selo lütseumis Peterburi lähistel. Kui novembris 1830 puhkes Poolas Novembriülestõus, kutsus Theodori onu feldmarssal I. I. Dibitsch noormehe Poolasse, kus ta osales Varssavi vallutamisel (Dzidzaria 1976: 7; Kagan 2002: 97-98). Poola ülestõusu mahasurumises mängis üht olulisemat rolli Leedu korpuse komandör parun Georg Andreas (Grigori) von Rosen (B. T-v 1913: 393), ühe vanema ja tuntuma baltisaksa suguvõsa esindaja. Kui 1831. aastal sai Rosenist Kaukaasia Erikorpuse komandör ja Kaukaasia administratsiooni juht, kutsus ta oma teenistusse ka Tornau. Saabudes 1832. aastal Tiflissi, sai Tornau ülesandeks Kaukaasia loodepiirkonna uurimine ja kirjeldamine. Peab rõhutama, et sel tööl olid eelkõige militaarsed eesmärgid. Selles osas erines Tornau nii oma kaasmaalasest Güldenstädtist kui ka teistest eelnimetatud saksa/baltisaksa uurijatest. Kui viimased olid teadlased, siis Tornau sõjaväelane, tema kirjeldused olid vajalikud eelkõige sõjaväele, ja nagu hiljem nähtus, osutusid need sõjaväele väga kasulikeks. Tänapäevases vene populaarteaduslikus kirjanduses on Tornaud nimetatud "Kaukaasia sõja

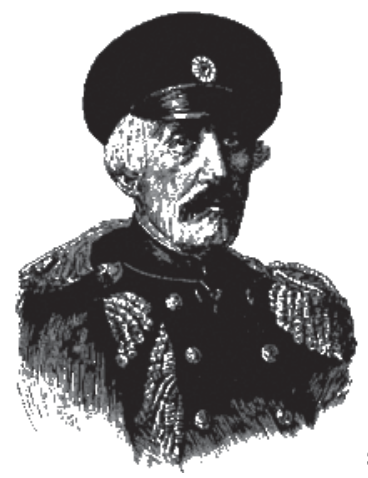
aegseks Stirlitziks” (Nikolin 2005: 44).

Kuid millised olid siis täpsemalt Tornau ülesanded Kaukaasias? Viimase Vene-Türgi sõja (1826-1828) järel 1829. aastal allkirjastatud Adrianopoli rahulepingu kohaselt oli Türgi ametlikult loobunud oma pretensioonidest Kaukaasia Musta mere rannikule. Sisuliselt kuulus kohalike rahvaste poolehoid aga jätkuvalt türklastele, kelle mõjuvõimu all oldi elatud mitusada aastat. Selleks, et türklaste mõju vähendada ja oma võimu tugevdada, otsustas tsaarivõim 1830. aastal rajada Abhaasia Musta mere ranniku-

Theodor von Tornau (de.vikipedia.org). 
le uusi kindlustusi. Selle ülesande täitjaks määrati baltisaksa kindral Carl (Karl Fjodorovitš) Hesse (Gesse), tollane Imereetia Vene administratsiooni juht. Vaenulikul maal kanda kinnitada polnud aga kerge. Abhaasiasse kavandati sõjakäiku, kuid selleks tuli esmalt saata piirkonda maakuulajad, kes teeksid kindlaks kohalike elanike hoiakud ja sidemed, omavahelised suhted ja kohalikud looduslikud olud. Iseäranis vajas Hesse informatsiooni ühendusteede kohta Abhaasiast üle mägede tšerkesside maadele ja Kubanisse. Sama 1830. aasta kevadel oligi komandeeritud saladuskatte all Abhaasiasse kindralstaabi porutšik parun I. K. von Asch (Dzidzaria 1976: 19, 22), taas kord saksa juurtega mees. Baltisaksa tausta pole tema puhul õnnestunud tuvastada. Asch jõudis Suhhumi aprillis 1830. Kogutud andmete põhjal koostas ta käsikirja "Abhaasia kirjeldus" (Opisanie Abhazii). Lisaks Aschile saadeti Abhaasiasse ka teisi luurajaid, kuid kõik viibisid seal lühiajaliselt ning nende märkmed olid ebatäpsed ja pealiskaudsed (Dzidzaria 1976: 23). Seega oli vaja kedagi, kes siirduks pikemaks ajaks mässulisse piirkonda ja suudaks seal infiltreeruda. Idee saata Abhaasiasse Tornau tuli Kaukaasia Erikorpuse komandörilt parun von Rosenilt, kes teda tundis ja usaldas. Tornau, noor ja ambitsioonikas sõjaväelane, pakkus end ka ise innukalt välja kui "ideelist luurajat", kes on valmis "tooma end ohvriks riigi huvide eest". Ise muidugi teades, et edu korral ootab teda tõus karjääriredelil (Dzidzaria 1976: 25). Tõsi, Tornau valdas tollal vaid mõne sõna tatari keelt, kuid ei ühtki kaukaasia keelt. Kuid kuna keelte paabel Kaukaasias oli suur, arvas ta, et alati tekib võimalus esitada end mõne rahva liikmena, mille keelt antud paigas ei osatud. Detsembris 1834 sõitis ta Tiflisist välja (Tornau 2008: 180). Jõudnud Abhaasiasse, õnnestuski tal õige pea saavutada usalduslikud suhted kohaliku üliku Aslan beiga ning tema kaudu jõuda ka teiste ülikuteni (Dzidzaria 1976: 28). Bamboris, mis oli tollal Vene administratsiooni keskus Abhaasias, tutvus ta Abhaasia vürsti Mihhailiga, kes oli võimule aidatud Vene relvade toel ja seetõttu paljude kohalike ülikute põlu all. Vürst ja Tornau jätsid üksteisele hea mulje. Tornau kirjutab, et vürst kinkis talle vintpüssi, mida ta sai hiljem pikka aega kasutada (Tornau 2008: 202).

Abhaasias viibides saatis Tornau pidevalt raporteid oma otsesele ülemusele Otto Hermann Christopher von der Howenile (venepäraselt Христофóp Христофо́рович Ховен, 1795-1890), Kuramaa taustaga ohvitserile nagu Tornau isegi. Sõjaväe topograaf Howeni peamiseks erialaks olid strateegilised ühendusteed. Enne Kaukaasiasse saabumist oli ta kaardistanud teid mitmel pool mujal olulistes piirkondades, sh Krimmis. Aastatel 1828-1830 oli ta olnud Teise armee peastaabis topograafide ülem ja 1833. aastal määratud Kaukaasia Erikorpuse staabiülemaks. Kaukaasiasse ei jäänud Howen küll kauaks - 1838. aastal määrati ta Siberi korpuse staabiülemaks, eelnevalt oli ta 1836. aastal edutatud kindralmajoriks (Veinberg 1901: 381-382). Tornau iseloomustas Howenit kui 
üht ausamat ja meeldivamat inimesi, keda tal on olnud õnn elus kohata (Tornau 2008: 170) - sellest saame välja lugeda, et nende koostöö sujus hästi. Küllap jõudsid siis ka Tornau raportid kiiresti armee ülemjuhatuseni.

Igatahes hindas väejuhatus Tornau raporteid, mida ta saatis Abhaasiast Howenile, väga kõrgelt. Juba pärast esimest retke ülendati Tornau staabikapteniks. Tema teine retk, mis algas septembris 1835, pidi esitama ülemjuhatusele andmeid Gagra kindluse ja Sotši jõe vahele jääva rannikupiirkonna kohta. Ohtlik oli olnud juba reis Abhaasiasse, kuid nüüdne reis, mis viis Tornau Abhaasia vürstiriigist põhja pool asuvate mässuliste hõimude maadele, kes ei tunnistanud venelaste võimu isegi nominaalselt, oli võrreldamatult ohtlikum. Tornau reisis inkognito varjunime Hassan all ja esitles end tšetšeenina. Oma kaaskonnaga, kelleks olid palgatud mehed Kaukaasia põliselanike seast, suheldi teiste kuuldes tatari keeles, mida Tornau teatavasti pisut oskas - lootuses, et teekonnal ei kohata ühtki tatari keele valdajat. Vene keelt kasutati vaid omavahel (Tornau 1868: 4-7). Eriti usalduslikud suhted kujunesid Tornaul selle reisi vältel ekspeditsiooni liikme Tembulat Karamurziniga, nogai vürstisuguvõsa liikmega, kes oli venelaste teenistusse astunud peamiselt ühel kaalutlusel - sooviga saavutada oma Saraatovi kubermangu küüditatud kogukonnakaaslastele amnestia (Dzidzaria 1976: 50). Pärast edukat teist reisi, mis suuresti tänu mägilastest kaaskonnale kulges suuremate ohuolukordadeta, avaldas Tornau Kaukaasia Erikorpuse komandörile parun von Rosenile Karamurzini palve: korraldatagu Karamurzini kogukonnale amnestia ja võimalus Saraatovi kubermangust kodumaale pöörduda. Rosen küll tõrkus, kuid viimaks soostus tsaarile palvekirja esitama, mille tsaar ka rahuldas (Dzidzaria 1976: 50).

Esimese ja teise reisi tulemused esitas Tornau novembris 1835 kolmeosalises ettekandes "Musta mere rannikulõigu kirjeldus Bsiba [Bzõbi] jõest Sashe [Sotši] jõeni", "Musta mere rannikut mööda kulgeva tee kirjeldus Gagra kindlusest kuni Sashe [Sotši] jõe suudmeni" ning "Üle Kaukasuse mägede ja piki Musta mere rannikut kulgeva kindustuste liini üksikasjalik kirjeldus Sotšist kuni Bzyba jõeni septembris 1835”. Need olid põhiliselt militaar-topograafilised andmed (Kagan 2002: 102).

Neist kirjeldustest huvitus tsaar Nikolai I isiklikult ja soovis, et just Tornau oleks edaspidi see, kes koguks luureandmeid Kaukaasia liini paremas servas Lääne-Kaukaasias. Kolmanda uurimisretke ülesande saigi Tornau 1836. aastal enam mitte Kaukaasia Erikorpuse komandörilt kindral von Rosenilt, vaid isiklikult tsaarilt - uurida rannikuala Sotši (Tornaul: Ssotscha) jõest põhja pool kuni Gelendžiki asulani (Tornau 1868: 44-47), seega peamiselt adõgeede ja ubõhhidega asustatud ala, kus tol perioodil osutati venelastele kõige ägedamat vastupanu. Mais 1836 lahkus Tornau Tiflisist ja sõitis Mineralnõje Vodõsse, kus veetis terve suve - peamiselt selleks, et kasvatada endale habe, 
mis aitaks paremini kohalike hulka sulanduda. Augustis siirdus ta Kaukaasia liini paremas servas paiknenud venelaste kindlusse Protšnõi Okop. Sealt pidid teda edasi saatma lojaalsed kabardid kuni Musta mere rannikuni (Tornau 1868: 49). Kuid nagu peagi selgus, polnud saatjad kuigi lojaalsed - varsti pärast Protšnõi Okopist teeleasumist salka rünnati, Tornau kisti hobuse seljast maha ja talt võeti ära relvad. Samuti 700 rubla raha, kuldkell ja hobuse sadul. Olukord tundus kriitiline, Tornau jõudis mõelda, et kahju oleks lahkuda elust 26aastasena... Kuid nagu selgus, ei soovinud mägilased teda tappa, vaid neid kannustas lootus lunarahale (Tornau 1868: 68, 70).

Nii algas Tornau vangistus kabardide juures, mis kestis üle kahe aasta. Kuna ta polnud röövijatele vastu hakanud, käituti temaga esialgu hästi. Tornau oli n-ö "mittevabatahtlik külaline" - lahkuda tal ei lubatud, kuid talle kohaldati mägilaste külalislahkuse seadust. See tähendas, et kui keegi on üle maja lävepaku astunud, tuleb teda kohelda külalisena ja talle vajadusel ka kaitset pakkuda. Kuid nagu tänapäevalgi ei soostu riigivõim kergekäeliselt terroristidele pantvangide eest lunaraha maksma, nii ka tookord. Selle asemel asusid tsaarivõimud Tornaud otsima ja piirkonda läbi kammima (Tornau 1868: 75jj). Tsaarivõimud tegid ettepaneku vabastada Tornau vastu üks venelaste käes vangis viibiv mägilane, kuid sellest Tornau röövijad keeldusid ning toimetasid ta teise auuli. Seal sai ta lähemalt tuttavaks kohalike elanike kommetega, nende lapsed õpetasid Tornaule isegi nende keelt (Tornau 1868: 113jj). Mais 1837 tegi Tornau esimese põgenemiskatse. Neli ööd rändas ta, süües rohtu ja lehti, kuni tabati ja toodi lähimasse auuli. Kuna tema uued vangistajad kartsid senise "omaniku" kättemaksu, andsid nad ta tollele välja (Tornau 1868: 135jj). Seekord pandi Tornau jalaahelatesse. Taas õnnestus tal põgeneda ja taas toodi ta tagasi. Lisaks senistele jalakettidele pandi talle nüüd ahel ka ümber kaela. Niimoodi veetis Tornau järgmised kolm kuud. Lõpuks aitas Tornau sõber Tembulat Karamurzin ta põgenema, kui ta "peremees" oli lahinguretkel venelaste vastu (Tornau 1868: 185jj). Mehed ratsutasid kahekesi Voznessenski kindlusse, sealt edasi kasakate saatel Kubanisse. Stavropolis kohtus Tornau vana tuttava kindral Paul Gustav Grabbega, keda ta nimetas oma esimeseks õpetajaks sõjanduses (Tornau 1868: 234). Grabbe, kelle baltisakslasest ema Justina Regina Häuser oli muide pärit Tartust ja kes tänu sellele kuulus ka Eestimaa rüütelkonda, oli äsja nimetatud Kaukaasia liini komandöriks (Vojennaja... 1912: 438-439).

Tornau vangistus oli kestnud ühtekokku kaks aastat ja kaks kuud (18361838). Kui tsaar kuulis Tornau vabanemisest, kutsus ta tema Peterburisse, et kuulda ta vangistuse-muljeid otseallikast. Tornau sõitiski läbi Moskva Peterburisse. Moskvas toimus südamlik kohtumine parun von Roseniga, kes oli vahepeal Kaukaasiast lahkunud. Peterburis leidis aset esinduslik tsaari 
vastuvõtt ja Tornaule omistati Püha Vladimiri ordeni neljas järk ja kapteni auaste (Tornau 1868: 235). Tornau kurtis tsaar Nikolaile Musta mere liini nõrkust ja rääkis vajadusest suurendada selle mehitatust. Ta avaldas arvamust, et ükski sealne kindlus ei pea vastu suurtükitulele merelt. Nikolai kuulas ta ära, kuid ei võtnud sisuliselt midagi ette. Järgnenud sündmused, eriti Krimmi sõda näitasid, et Tornaul oli olnud õigus (Makarova 2008: 9).

Vaatamata vintsutustele Kaukaasia vangistuses lahenes kõik kokkuvõttes hästi. Kuigi võiks arvata, et Tornau sinnakanti enam tagasi ei kippunud, oli ta juba 1840. aastal uuesti Musta mere idarannikul ning osales mais ja juunis sealsetes sõjalistes operatsioonides, ühtlasi ka ühe uue vene kindluse rajamisel. Hiljem, 1843. aastal saadeti Tornau teenistusülesannetes Dagestani (Kagan 2002: 111).

Esimest korda ilmusid Tornau mälestused 1864. aastal ajakirjas Russkii Vestnik (Русский Вестник), hiljem ka eraldi raamatutena, sh tõlgetena. Autor paistab silma hea sulejooksuga, tema tekst sisaldab hulgaliselt biograafilisi seiku ja põnevaid arutlusi. Silmas tuleb muidugi pidada, et mälestused on retrospektiivsed, kirjutatud elukogenud mehe poolt paarkümmend aastat hiljem ja kaugel sõjakärast. Nimelt oli Tornau 1856. aastal, kaheksa aastat enne Kaukaasia sõja lõppu, asunud tööle Viinis tsaaririigi saatkonna sõjaväeatašeena (Kagan 2002: 114).

Tornau mälestused sisaldavad hulgaliselt etnograafilisi tähelepanekuid, neis kirjeldatakse kohalike rahvaste elu-olu, rõivastust, elamuid, elatusalasid, tavasid. Oma teisel reisil viibis ta pikemalt abhaaside ahtšipsõ kogukonna asulas Mzõmta jõe ääres - sealsamas, kuhu eesti väljarändajad pool sajandit hiljem 1886. aastal oma Eesti Aiakese asunduse rajasid, mistõttu võiksid Tornau kirjeldused piirkonnast (Tornau 1868: 8-13) huvi pakkuda ka Kaukaasia eesti asunduste ajaloo seisukohalt.

Tornau raportites ja mälestustes on juttu piirkonna paljudest rahvastest. Kirjutades erinevate rahvaste etnilistest ja geograafilistest piiridest, märgib ta, kui hädas oli ta tollaste topograafiliste kaartidega - kohalike rahvaste paiknemise osas olid need vigu täis. Vead tulenesid tema sõnul sellest, et paljudesse piirkondadesse polnud uurijad veel sattunud ja kui sattusidki, ei osatud kohalikke keeli. Põliselanikud ei osanud aga vene keelt. Nii ajasidki varasemad autorid segamini hõimud ja rahvad, nimetades neid ilma igasuguse korrata kord nii, kord naa (Tornau 2008: 267). Aga seda nägime juba 18. sajandi lõpu ja 19. sajandi alguse kirjutiste ülevaatest.

Kuid nüüd meid peamiselt huvitava teema juurde. Kui vaadata, mida kirjutas Tornau džigettide ja abhaaside paiknemisest ja omavahelisest piirist, tuleb rõhutada, et tema teadmised olid üsna põhjalikud - kui senised autorid olid džigettidest kas üldse mööda läinud või kirjutanud neist üldistavalt, siis 
Tornau eristab ka nende erinevaid kogukondi (Tornau 1839: 109) ja täiesti arusaadav, sest ta viibis neis paigus pikemat aega. Ta eristab džigette abhaasidest geograafiliselt - nendevaheliseks piiriks nimetab ta Bzõbi jõge. Samas nimetab ta abhaase ja džigette hõimukaaslasteks (odnoplemennõje) (Tornau 2008: 205). Ta kirjutab abhaaside ja džigettide keelelisest lähedusest - nad mõistavad üksteise kõnet (Tornau 1835: 119). Ühes 1832. aastal koostatud raportis kasutab Tornau Inguri ja Sashe [Sotši] jõgede vahel (seega Abhaasia vürstiriik koos Džigetiaga) elava rahvastiku tähistamiseks mõistet "abasiini hõim" (племя абазин). Tornau märgib, et neil on ühine keel, mis erineb tšerkesside keelest (Tornau 1839: 109). Selle kirjelduse järgi pole siis abhaasid ja džigetid isegi mitte hõimukaaslased, vaid üks ja seesama rahvas ühise keelega.

Nagu juba öeldud, peetakse Tornau kirjalikke aruandeid piirkonna geograafia ja elanikkonna kohta tolle aja kõige täpsemateks ja seega olulisemateks, neile viitavad nii Vene kui ka Abhaasia autorid. Kuid nagu neist Tornau tsitaatidest näeme, võib neid mõista teatava nüansierinevusega: džigetid olid abhaasidega sama rahvas või neile väga lähedane rahvas, nad rääkisid nendega sama keelt või väga lähedast murret. Seega omast kohast on õigus Abhaasia autoril Shalva Inal-ipal, kui ta Tornaule tuginedes vaidleb tuliselt vastu neile, kes sadze/džigette abhaaside hulka ei arva (Inal-ipa 1995: 55). Kuid päriselt ei saa valeks pidada ka vene autori Ekaterina Arhipova väidet, kui ta Tornaule tuginedes järeldab, et Abhaasia etniline ja poliitiline piir jooksis tol ajal mööda Bzõbi jõge (Arhipova 2014: 45). Poliitiliselt oli asi selge: Džigetia oli tollal tõesti Abhaasia vürstiriigist sõltumatu. Arhipova väide abhaaside ja džigettide etnilisest erinevusest on aga pigem poliitiliselt motiveeritud.

Abhaasi autorid kasutavad oma väidete kinnituseks ka Tornau-järgseid autoreid. Näiteks 1840. aastatel Musta mere rannikuliinil tegutsenud kindral Grigori Ivanovitš Filipsoni teateid, et sadzid räägivad "puhast abhaasi keelt" (tsit Atšugba 2012: 8). Ka saksa õpetlane Friedrich Martin von Bodenstedt, kes 1840. aastatel piirkonnas rändas, kirjutas: "Abhaasia ja Džigetia elanikud nimetavad end oma ühises keeles apsuadeks ja oma maad, mis asub rannikul, Apsneks" (Bodenstedt 1849: 196). Bodenstedti võib usaldada - kui ta 1840. aastatel neis paigus reisis, peatus ta ka Adleri (Ardilleri) kindluses, mille komandandiks oli tollal Vene armees majori auastmesse jõudnud džigeti päritolu Svan-bei, nooruses venelaste kätte vangi sattunud ja Peterburis sõjaväelase hariduse saanud mees. Just temalt sai Bodenstedt informatsiooni džigettide kohta (Bodenstedt 1849: 194).

18. sajandi lõpu ja 19. sajandi esimese poole autorite tähelepanekud on niisiis olulised, kui tahame teada, kes olid Väike-Abhaasia elanikud džigetid etniliselt. Piirkonnast saadeti nad 1860. aastatel välja Osmani impeeriumisse. Tänapäeval on nende kogukonnad osalt säilinud Türgis, aga ka Gruusia Adžaarias, 
Jordaanias ja Süürias, mis väljasaatmise ajal jäid Osmani impeeriumi piiresse (Inal-ipa 2015: 105; Tšatšhalia 2012: 102).

Türgis Adapazarõ linna (Sakaria vilajett) lähistel asub üle tosina küla, mille elanikud peavad end tänase päevani sadzi abhaasideks. Abhaasia keeleteadlased on korraldanud mitmeid ekspeditsioone oma Türgis elavate suguvendade juurde. Küsimusele, kelleks sealsed elanikud end peavad, vastatakse, et apsuadeks. Vahel ka täpsustatakse: me oleme sadzi abhaasid. Selle kohta, et sadzid tunnevad ühtekuuluvust abhaasidega, annab tunnistust ka tõik, et Gruusia-Abhaasia sõjas 1992-1993 võitles mõnikümmend välis-sadzi/džigetti abhaaside poolel.

Krasnaja Poljana (abhaasi k Kbaada, Gbaada) aladelt küüditatud ahtšipsõabhaasid Türgis elavad mägede vahel Bõtška külas. Küla asukoht sarnaneb Krasnaja Poljanaga Mzõmta jõe kaldal. Nimelt otsisid oma kodupaigast võõrsile kihutatud abhaasid kaua kohta oma uuele kodule ja valisid paiga, mis maastiku poolest meenutab nende kodupaika Kaukaasias. Ka nende küüditatute järglased peavad end apsuateks ja mitte abasiinideks. Seda on oluline rõhutada, sest Venemaal leidub teadlasi, kes üritavad väita, justkui oleksid Krasnaja Poljana piirkonnas ja mujal Mzõmta ja Psou jõgede ülemjooksul elanud 19. sajandil enne küüditamisi abasiinid (Argun 2012: 18-19; Tšatšhalia 2012: 102). Probleem on seega sarnane džigeti-küsimusega: piirialade rahvaste etniline kuuluvus ei lahendaks ilmselt piiriprobleeme, kuid annaks vaidluspooltele sümboolset kapitali ja moraalset tuge oma seisukohtade kaitsmiseks. Niisiis on tänapäeva abhaasi teadlaste ekspeditsioonidel Türgisse puhtteaduslike eesmärkide kõrval ka poliitilised sihid.

\section{Abhaasia-Venemaa piirivaidlused kaasajal: Aibga}

Poliitiline mõõde on sel teemal kindlasti. Nimelt kui pärast 2008. aasta VeneGruusia sõda tunnustas Vene Föderatsioon Abhaasia Vabariigi iseseisvust, algas peagi Vene poole initsiatiivil töö Vene-Abhaasia piiri fikseerimiseks. Nagu eespool mainitud, moodustati 2010. aastal vastavad komisjonid. Need tunnustasid üksteise territoriaalset terviklikkust ja piiride puutumatust, sh kehtivat piiri Psou jõel, mille vasakkaldal asub ka eestlaste Salme küla. Kuid juba teisel komisjonide kohtumisel esitas Vene pool abhaasidele territoriaalseid nõudmisi. Väideti, et Abhaasiaga liideti Nõukogude ajal ebaseaduslikult Vene Föderatsioonile kuuluv piirkond Gagra rajoonis 160 ruutkilomeetri ulatuses. Probleemi juured on varasemates kümnendites. Nägime eespool, et 19. sajandil kuulus Džigetia vaid lühikest aega Abhaasia vürstiriigi koosseisu. 1847. aastal liideti Bagripsta jõest põhja poole jääv osa Džigetiast Musta mere kubermanguga, 
1904. aastal liideti Musta mere kubermanguga ka ülejäänud Džigetia. Kodusõja ajal hõivas Abhaasia territooriumi Gruusia Demokraatliku Vabariigi armee ja 1920. aasta Moskva rahuleping Gruusia ja Nõukogude Venemaa vahel nihutas piiri Psou jõele ning Abhaasia (tegelikult muidugi seda okupeeriv Gruusia) sai tagasi suurema osa Džigetiast. Kui aga Punaarmee vallutas 1921. aasta kevadel Abhaasia, moodustati sellest Abhaasia NSV, kuid taas, nagu 1847. aastal, lõigati selle küljest ära piirkond põhja pool Bagripsta jõge ja liideti Pilenkovo valla nime all Vene SFNV Sotši rajooniga.

Niisiis jätkus Džigetia-saaga ka nõukogude ajal. Suures osas kattus Pilenkovo valla territoorium ajaloolise džigettide Tsandripši kogukonna maadega. Valla see osa, mis jäi Psou ülemjooksule, oli 19. sajandil olnud abhaasi aibga kogukonna valdus (Kvartšija 2019a: 35, 239, 246). Pilenkovo valla piiresse jäid ka eestlaste Salme ja Sulevi, st needki läksid Abhaasia NSV koosseisust Vene SFNV koosseisu. Abhaasia NSV juhtkond esitas korduvaid proteste ja 31. detsembril 1928 otsustas Ülevenemaalise Kesktäitevkomitee presiidium anda Pilenkovo piirkonna neli külanõukogu tagasi Abhaasiale. Ka eestlaste Salme ja Sulevi läksid nüüd uuesti Abhaasia koosseisu. Viienda, Aibga külanõukogu, staatus jäi aga ebaselgeks. Nimelt asub Aibga piirijõe Psou mõlemal kaldal. Ametlikult jäeti Aibga tervenisti Vene SFNV koosseisu, otsust põhjendati asula vene elanikkonnaga ning selle majanduslike ja kultuuriliste vajadustega. Kuid abhaasi teadlased ja poliitikud väidavad tänapäeval, et see otsus oli õigustühine, kuna võeti vastu Abhaasia NSV ja Gruusia NSV nõusolekuta. Ühepoolne piiri muutmine oli aga vastuolus Nõukogude Liidu 1924. aasta konstitutsiooniga. Abhaasia pool argumenteerib ka sellega, et paljudel nõukogudeaegsetel kaartidel on Aibga Abhaasia osa (Kvartšija 2019a: 246, 272, 273).

Kogu nõukogude aja vältel jäi piiriprobleem Aibgas sisuliselt lahendamata, piirkonna maid kasutasid nii Abhaasia Gagra rajooni kui ka Vene NFSV Adleri rajooni majandid. Kuna tegemist polnud riigi välispiiriga, ei tekitanud see liigseid probleeme. Pärast Nõukogude Liidu kokkuvarisemist ja GruusiaAbhaasia sõda, mille tagajärjel Abhaasia faktiliselt iseseisvus, on aga pinged teravnenud. Abhaasia pool hakkas takistama Vene põllumajandusettevõtjate tegevust, kes majandasid Psou vasakkaldal ilma Abhaasia poole loata. Vene pool takistas omakorda Abhaasia sõidukite liikumist Aibgasse teelõigul, mis seitsme kilomeetri ulatuses jooksis Vene Föderatsiooni territooriumil. Abhaasia ehitas seepeale ühendustee oma territooriumile. Väidetavalt vene ettevõtjate initsiatiivil, kes olid toimetanud Psou vasakkaldale jäävas Aibga osas, algas Vene ajakirjanduses kampaania, et veenda lugejat selle territooriumi kuulumises Venemaale. Abhaasia peab vasakkallast aga jätkuvalt enda territooriumiks (Kvartšija 2019a: 278-282). 
Aigba on tegelikult väike asula. 2011. aasta andmetel elas Aibgas 29 Vene Föderatsiooni kodanikku, kes olid sisse kirjutatud Krasnodari krai Adleri rajooni Nižne-Šilovskoje asulasse. Viimane asub Salme küla vastas teispool Psou jõge. Aibga küla, kus puudub elekter, kool jm infrastruktuur, tekitab pingeid jätkuvalt (Kvartšija 2019a: 180-184, 2019b: 242).

Meie jaoks teeb Aibga huvitavaks eelkõige asjaolu, et külal on seos ka eestlastega. Vene koloniaalvõimud tegid juba 1868. aastal otsuse rajada tänase Aibga kohale vene küla. Nagu kirjutab piirkonna ajalugu uurinud abhaasi ajaloolane Valeri Kvartšija, algas asustustegevus aga alles 1888. aastal, kui saabusid asunikud Valgevene aladelt (Kvartšija 2019a: 241). Eestlasi ta ei maini, kuid leidub andmeid, mille kohaselt olid esimesed asunikud hoopis eestlased. Punase Lagedalt pärit eestlane August Ingerman (Ingermaa) on Aibgad nimetanud eesti-vene segakülaks, mida eestlased kutsusid ka Nahipiks (August Ingerman, Minu mälestusi Ritsa järvest - EAM 284.1.40, 1 4). Ingermani andmeil elas Aibgas kümme eesti peret (Ingermaa s.a.: 17), kuid pole teada, missugusest perioodist jutt käib. Johannes Kirkmann, Punase Lageda eesti kooliõpetaja kirjutas 1912. aastal, et tollal elas Aibgas viis eesti perekonda, varem aga rohkemgi. Kirkmanni andmeil rändasid eestlased Aibgasse 1887.-1888. aastal, peamiselt Põhja-Kaukaasia Livoonia eesti asundusest. Mõni aasta hiljem lisandus umbes 70 peret venelasi. Kuna eestlaste poolt ülesharitud maad läksid suures osas venelaste kätte, tekitas see eestlaste ja venelaste vahel tülisid ning eestlased rändasid peagi suuremas osas minema (Kirkmann 1912: 2). Internetisaidi Šapsugia andmeil, mis muuseas tunnistab küla esmasteks kolonistideks eestlased, oli 1901. aastal küla 277 elanikust slaavlasi 246, 1904. aastal elas külas 360 slaavlast ja 30 eestlast. Selleks ajaks oli külas sisserändajaid lisaks Liivimaa kubermangule ka Kaluuga, Kiievi, Kurski, Volõõnia, Voroneži, Jekaterinoslavi, Stavropoli, Musta mere, Saraatovi, Orlovi, Tambovi, Tuula, Mogiljovi, Podolski, Tauria, Tšernigovi, Poltaava ja Harkovi kubermangudest ning Kubani ja Doni oblastitest. ${ }^{5}$ Johannes Kirkmann kurdab, et allesjäänud eestlased elavad oma vähesuse tõttu "ilma kõige vähema vaimlise äratuseta", ja ennustab, et peagi sulanduvad nad venelaste hulka. Eestlastest oskasid veel vaid vanemad inimesed eesti keeles lugeda ja mõned ka kirjutada, kuid noored, kes käisid kohalikes vene koolides, olid juba venestunud. Kirkmanni andmeil käis külla vähemalt üks eesti ajaleht (Kirkmann 1912: 2). Aibga asub Punase Lagedalt 18 km kaugusel, ja nagu tunnistab oma mälestustes August Ingermaa, käisid Punase Lageda eesti mehed Aibga kandi metsades jahil (Ingermaa s.a.: 12). Nagu olen kuulnud oma Salme ja Sulevi informantidelt, on Sulevi küla eestlased Nõukogude ajal ja hiljemgi kasutanud Aibga piirkonnas asuvaid paiku suvekarjamaadena. 
Aibga on selles mõttes erandlik küla Abhaasias, et talle jäi ka kolonistide saabudes alles varasematest asukatest pärit nimi. Ilmselt aitas nime kinnistada see, et pärast Kaukaasia sõja (1817-1864) lõppu rajati senistest asukatest puhastatud asula kohale garnison, mis sai 1869. aastal ametlikuks nimeks Selenie Aibga $^{6}$ - garnisoni nimi kandus hiljem kolonistide asulale. Kohalike eestlaste (ja ilmselt ka venelaste) kasutatud nimekuju Nahip on mugandus Aibgast.

Enne venelaste vallutusi asustas Aibga piirkonda aga samanimeline ( $а и ̆ b \iota \sigma_{a}$ ) abhaasi kogukond. Kui Abhaasia vürstiriik muudeti 1810. aastal Venemaa protektoraadiks, keeldusid aibgad koos mitmete teiste abhaasi mägihõimude ja džigettidega Vene võimule allumast. Aastakümneid osutasid nad venelastele vastupanu ja olid ühed viimastest, kes Kaukaasia sõjas alistuma sunniti (Atšugba 2012: 10; Tširikba 2012: 22-23). Sõda lõppes 1864. aastal ja juba 1865. aastaks olid aibgad koos teiste mässumeelsete kogukondadega piirkonnast täies koosseisus minema aetud (Kvartšija 2019a: 241).

Samamoodi nagu džigettide puhul, võib küsida ka nüüd: kes olid aibgad? Mõned vene autorid on neid nimetanud abasiinideks (Argun 2012: 19). ${ }^{7}$ Kui see nii oleks, annaks see sümboolset kapitali Vene poolele piirivaidlustes Abhaasiaga. Abasiinid on teatavasti rahvas tänapäeva Karatšai-Tšerkessi Vabariigis Vene Föderatsioonis - abhaasidele etniliselt lähedane, kuid mitte seesama etnos. Kuna aibgad aeti piirkonnast minema, pole seal enam kellegi käest küsida nende päritolu ja etnilise kuuluvuse kohta. Ka nüüd on oluliseks allikaks 1830. aastatel piirkonnas reisinud baltisaksa ohvitseri Theodor von Tornau andmed, mille kohaselt kuulusid aibgad, keda oli tollal 180 perekonda, abhaaside hulka (Tornau 1835: 105).

Tänapäeval elab Aibga kogukonna liikmete järglasi ka Türgis - ka nemad nimetavad end abhaasideks ja eristavad end nii abasiinidest kui džigettidest (Argun 2012: 18, vt ka Inal-ipa 1995: 55). Seega jääb tänastele abhaasidele vähemalt teadmine, et Abhaasia etniline piir ulatus enne tsaaririigi invasiooni kaugemale riigi tänasest poliitilisest piirist. Ja kindlasti lisab see teadmine neile söakust vastu vaielda Vene poole territoriaalsetele pretensioonidele. Valeri Kvartšija, abhaasi ajaloolane, aga ühtlasi Abhaasia Vabariigi poolse VeneAbhaasia riigipiiri määratlemise komisjoni esimees, on oma argumentatsioonis Vene komisjonile tõstnud esile ka 19. sajandil Abhaasiale osaks saanud ülekohtu teema. Ühes vastuses Vene piirikomisjonile deklareerib ta, et just Venemaa likvideeris 1864. aastal Abhaasia vürstiriigi, samas rõhutab, et ka pärast tsaaririigi kokkuvarisemist 1917. aastal valitses Abhaasi Rahva Nõukogu Abhaasiat tema ajaloolistes piirides Mzõmta ja Inguri jõgede vahelisel territooriumil (Kvartšija 2019a: 268), seega siis ka hiljem kaotatud osa Džigetiast. Muidugi teab Kvartšija, et Abhaasi Rahva Nõukogu võim tol keerulisel kodusõja ajal oli 
nõrk, pealegi jäi selle võimuperiood tookord üürikeseks, ta teab, et Gruusia ja Venemaa omavahelistes üle abhaaside peade 1920. aastal sõlmitud sobingutes fikseeriti piir Psou jõel, muidugi teab ta ka seda, et venelastel pole kombeks anda kellelegi tagasi jalatäitki tänase Vene Föderatsiooni territooriumist. On tähelepanuväärne, et Kvartšija on oma Vene poolele esitatud ametlikus argumentatsioonis kasutanud ka baltisakslase Theodor von Tornau andmeid (Kvartšija 2019a: 241, 268). Alates 2015. aastast pole aga piirikomisjon enam koos käinud ja Aibga küsimus on jäänud lahenduseta (Kvartšija 2019a: 240). Sisuliselt on tegemist külmutatud konfliktiga.

\section{Kokkuvõte}

Sarnaselt Gruusia ja Armeeniaga kuulub Abhaasia nende maade hulka, kelle ajalugu on suurem nende tänasest poliitilisest kaalust ja kelle piirid ulatusid minevikus palju kaugemale tänastest piiridest. Abhaasia põhjapiir ulatus keskajal kuni Kubani jõeni, hilisematel sajanditel on see nihkunud üha lõuna poole ja õgvendanud Abhaasia territooriumi tunduvalt väiksemaks. 19. sajandi alguses ulatus Abhaasia vürstiriigi piir Bzõbi jõeni, mis tähendas, et Džigetia jäi Abhaasia piiridest välja. Sajandi keskel liideti Abhaasiaga lühikeseks ajaks ka Džigetia, vürstiriigist põhja pool asuv etniliselt lähedase elanikkonnaga piirkond, kuid peagi lahutati sellest taas. Abhaasia loodepiir, mis korraks Džigetia liitmisega nihkus Mzõmta jõeni, liikus tagasi Bzõbile. Abhaasia vürstiriik likvideeriti, selle lõunaosa liideti Kutaisi kubermanguga, loodeosa Musta mere kubermanguga. Selline oli seis ka 1917. aastal, kui tsaaririik kokku varises. Gruusia ja Venemaa vahel sõlmitud Moskva rahulepingu kohaselt liikus piir Psou jõele.

Väljaarvatud mõningad piirinihutused 1920. aastatel, püsis Nõukogude ajal Vene-Abhaasia piir Psou jõel, ja on seal tänini. Viimasel kümnendil on Venemaa aga esitanud territoriaalseid pretensioone Abhaasiale ajaloolise Džigetia piirkonnas. Ka Vene teadlasringkondadest kuulutatakse, et Džigetia ei kuulu ajaloolis-etniliselt Abhaasia piiresse. Kuna kohalik rahvastik, kellelt infot küsida, küüditati tsaarivõimude poolt juba poolteist sajandit tagasi, kasutatakse argumentidena 18. sajandi teise poole ja 19. sajandi esimese poole baltisaksa autorite seisukohti. Artiklis analüüsiti saksa, sh baltisaksa maadeuurijate ja maakuulajate andmeid Loode-Kaukaasia, sh Abhaasia rahvastiku kohta. Artikli põhifookuses olid Abhaasia loodepiirkonna, sh Džigetia kirjeldused, eriti need, mis pärinevad Kuramaa juurtega Theodor von Tornault. Tornau käsitluse põhjal 
võib järeldada, et džigetid olid abhaaside etniline rühm. Etnilisele printsiibile tuginedes tõrjub Abhaasia tänapäeval Venemaa-poolset survet abhaasi aladele.

Lõpetuseks võib küsida, miks tuginetakse selles vaidluses just saksa ja eriti baltisaksa ja mitte näiteks vene autorite tekstidele. Põhjused ulatuvad 18. sajandi esimesse poolde, mil Lääne-Euroopat eeskujuks seadnud Peeter I initsiatiivil loodi Peterburi Teaduste Akadeemia ja selle liikmeteks kutsuti valdavalt saksa teadlased. On seega mõneti loogiline, et akadeemia organiseeritud teadusekspeditsioonid mehitati peamiselt saksa teadlastega. Aja jooksul omandasid nende seas järjest suurema kaalu Baltikumist, st Vene tsaaririigi piirest pärit sakslased. Vene teadusega paralleelselt "germaniseerus" ka Vene armee ja kui 19. sajandi teisel kümnendil alustas tsaaririik Kaukaasia vallutamist, moodustasid ka seal sõjalisi operatsioone läbi viiva Kaukaasia Erikorpuse juhtkonnast silmatorkava osa baltisakslased. Nii oli see Kaukaasia sõja lõpuni. Kui Kaukaasiasse korraldatud teadusekspeditsioonid omandasid sõja käigus üha militaarsema iseloomu, asendusid teadlastest maadeuurijad ohvitseridega, kuid baltisaksa taust oli nendelgi.

\section{Kommentaarid}

1 Läbi tsaari-ja nõukogude aja kasutati peamiselt regioonile viitavat mõistet "Kaukaasia eestlased". "Abhaasia eestlased" on mõistena laiemalt käibesse jõudnud alles pärast Abhaasia de facto eraldumist Gruusiast 1993. aastal.

2 Seega osaliselt tänapäeva Abhaasia Vabariigis, osaliselt Vene Föderatsiooni Krasnodari krais. Mitte segamini ajada Väike-Abazaga.

3 Abhaasi autorid seostavad sadze antiikmaailmas tuntud sanigidega, keda mainib Plinius Vanem 1. saj eKr. Seos pole siiski kindel, Gruusia autorid peavad sanige grusiinide svaani etnilise grupi esivanemateks, mõned peavad neid ka mingeelide esivanemateks (vt Inal-ipa 1995: 16-17).

4 Abasiinid - abhaaside sugulasrahvas Põhja-Kaukaasias, kellest suurem osa saadeti 19. sajandi teisel poolel välja. Küüditamata jäänud abasiinide järeltulijad elavad tänapäeval peamiselt Vene Föderatsiooni Karatšai-Tšerkessia Vabariigis (Argun 2012: 17; Tširikba 2012: 22).

${ }^{5}$ https://www.shapsugiya.ru/index.php?newsid=3647 (vaadatud 22.04.2021).

6 https://www.shapsugiya.ru/index.php?newsid=3647 (vaadatud 22.04.2021).

7 Vt ka: https://www.shapsugiya.ru/index.php?newsid=3647 (vaadatud 22.04.2021). 


\section{Arhiivimaterjalid}

EAM (Eesti Ajaloomuuseum) 284.1.40. August Ingerman. Minu mälestusi Ritsa järvest.

\section{Kirjandus}

Argun, Juri 2012 = Argun, Iu. G. Ob etnicheskoi situatsii na territorii mezhdu Sochi i Gagroi v nachale XIX v. Achba, A. O. (vastutav toim). Dzhigetskii sbornik I. Voprosy etno-kul'turnoi istorii Zapadnoi Abkhazii ili Dzhigetii. Moskva: AKVA-Abaza, lk 13-21.

Arhipova, Ekaterina 2014 = Arkhipova, E. V. Gosudarstvennye granitsy Rossii na Kavkaze: formirovanie i sovremennye problemy bezopasnosti. Volgograd: Izdatel'stvo Volgogradskogo gosudarstvennogo universiteta.

Atšugba, Teimuraz 2012 = Achugba, T. A. 2012. Ob etnicheskoi nomenklature naseleniia sadzskoi Abkhazii v per. pol. XIX v. Dzhigetskii sbornik I. Voprosy etno-kul'turnoi istorii Zapadnoi Abkhazii ili Dzhigetii. AKVA-Abaza, Moskva, lk 7-12.

Benno, Agur 2018. Moritz von Kotzebue, tema aeg ja mõned teda ümbritsevad isikud. Kotzebue, Moritz von. Teekond Pärsiasse (tõlkinud Agur Benno). Loomingu Raamatukogu 15-17. Tallinn: SA Kultuurileht, lk 129-134.

Bodenstedt, Friedrich 1849. Die Völker des Kaukasus und ihre Freiheitskämpfe gegen die Russen. Ein Beitrag zur neuesten Geschichte des Orients. Frankfurt am Main: Verlag Carl Bernhard Lizius.

B. T-v. 1913 = B. T-v. Rozen, baron Grigorii Vladimirovich'. Russkii biograficheskii slovar'. Tom XVI. S.-Peterburg: Tipografiia Imperatorskoi Akademii Nauk, lk 391-398.

Dzidzaria 1976 = Dzidzariia, G. A. F. F. Tornau i ego kavkazskie materialy XIX veka. Moskva: Nauka.

Engelhardt, Moritz von \& Parrot, Friedrich 1815. Reise in den Krym und den Kaukasus. Erster Theil. Berlin: Realschulbuchhandlung.

Güldenstädt, Johann Anton 1787. Reisen durch Rußland und im Caucasischen Gebürge I. St. Petersburg: Kayserliche Akademie der Wissenschaften.

Inal-ipa, Shalva 1995 = Inal-ipa, Sh. D. Sadzy. Istoriko-etnograficheskie ocherki. Moskva: Rossiiskaia Akademiia Nauk.

Inal-ipa, Shalva 2015 = Inal-ipa, Sh. Ob izmenenii etnicheskoi situacii v Abhazii XIX v. Achugba, T. A. \& Achugba, D. T. (koost). Stranitsy gruzino-abhazskoi informatsionnnoi voiny. Dokumenty i materialy. Tom I. Suhum: AbIGI, lk 96-108.

Ingermaa, August s.a. Mõnda mälestusi Punaselageda eesti asundusest Kaukaasias, lk 17 (https://ida.aule.ee/kirjutised/ingermaa.pdf - vaadatud 13. mai 2021). 
Kagan, Gennadi F. 2002. Biographie des Barons F. F. Tornau. F. F. Tornau. Ein Russe im k. u. k. Wien. Das Wiener Tagebuch des Barons F. F. Tornau. Wien \& Köln \& Weimar: Böhlau Verlag, lk 97-115.

Kirkmann, Johannes 1912. Eesti asundused Mustamere kubermangus, Kaukasias. Postimees nr 138, 19. juuni, lk 2.

Klaproth, Heinrich Julius von 1812. Reise in den Kaukasus und nach Georgien unternommen in den Jahren 1807 und 1808, auf Veranstaltung der Kaiserlichen Akademie der Wissenschaften zu St. Petersburg, enthaltend eine vollständige Beschreibung der Kaukasischen Länder und ihrer Bewohner. Erster Band. Halle \& Berlin: Waisenhaus.

Klaproth, Julius von 1814. Reise in den Kaukasus und nach Georgien unternommen in den Jahren 1807 und 1808, auf Veranstaltung der Kaiserlichen Akademie der Wissenschaften zu St. Petersburg, enthaltend eine vollständige Beschreibung der Kaukasischen Länder und ihrer Bewohner. Zweiter Band. Halle \& Berlin: Waisenhaus.

Kotzebue, Moritz von 2018. Teekond Pärsiasse (tõlkinud Agur Benno). Loomingu Raamatukogu 15-17. Tallinn: SA Kultuurileht.

Kruusmaa, Krister 2020. Moritz von Engelhardti ja Friedrich Parrot' reis Krimmi ja Kaukasusse 1811. aastal - Tartu Ülikooli uurimisreiside eelkäija. Bakalaureusetöö. Tallinn: Tallinna Ülikool.

Kvartšija, Valeri 2019a = Kvarchiia, V. E. Sobranie trudov v semi tomakh. Tom II. Toponimika. Gosgranitsa. Sukhum: Akademia.

Kvartšija, Valeri 2019b = Kvarchiia, V. E. Sobranie trudov v semi tomakh. Tom IV. Istoricheskaia toponimika. Sukhum: Akademia.

Makarova 2008 = Makarova, S. E. 2008. Vospominaniia kavkazskogo ofitsera. Tornau, Fedor F. Vospominaniia kavkazskogo ofitsera. Moskva: AIRO-XXI, lk 5-10.

Nikolin 2005 = Nikolin, S. Puteshestviia po skazochnomu kraiu. Krasnaia poliana - put' $k$ mechte. Rostov-na-Donu: Donskoi izdat. dom.

Pallas, Peter Simon 1787. Vorrede. Güldenstädt, Johann Anton. Reisen durch Rußland und im Caucasischen Gebürge I, S. VII-XVI. St. Petersburg: Kayserliche Akademie der Wissenschaften.

Pallas, Peter Simon 1803. Bemerkungen aufeiner Reise in die südlichen Statthalterschaften des Rußischen Reichs in den Jahren 1793 und 1794. Leipzig: Bey Gottfried Martini.

Richmond, Walter 2008. The Northwest Caucasus. Past, present, future. London, New York: Routledge.

Schüler, Mechthild \& Rohlfing, Helmut 1998. Das “neu entdeckte Land”: wissenschaftliche Expeditionen nach Sibirien im 18 und 19 Jahrhundert. Sibirien, Finnland, Ungarn. Finnisch-ugrische Sprachen und Völker in der Tradition eines Göttinger Sondersammelgebietes. Göttinger Bibliotheksschriften 10. Göttingen, lk 63-83 (doi: 10.17875/gup1998-627). 
Tornau, Fedor 1835 = Tornau, F. F. 1835 (1976). Obychai abkhazskogo naroda i razdelenie ego na sostoianiia. Dzidzariia, G. A. F. F. Tornau i ego kavkazskie materialy XIX veka. Moskva: Nauka, lk 119-125.

Tornau, Fedor 1839 = Tornau, F. F. 1839 (1976). Kratkii obzor gorskim plemenam, zhivushchim za Kuban'iu i vdol' vostochnogo berega Chernogo moria, ot ust'ia Kubani do ust'ia Ingura. Dzidzariia, G. A. F. F. Tornau i ego kavkazskie materialy XIX veka. Moskva: Nauka, lk 109-119.

Tornau, Theodor 1868. Erinnerungen eines Offiziers des Kaukasischen Corps. Zweiter Band. Berlin: Otto Janke.

Tornau, Fedor 2008 = Tornau, F. F. Vospominaniia kavkazskogo ofitsera. Moskva: AIRO-XXI.

Tšatšhalia 2012 = Chachkhalia, D. K. 2012. Dzhigetiia na politicheskoi i etnograficheskoi karte Abkhazii. Chachkhalia, D. K. (peatoim). Dzhigetskii sbornik I. Voprosy etnokul'turnoi istorii Zapadnoi Abkhazii ili Dzhigetii. Moskva: AKVA-Abaza, lk 97-102.

Tširikba 2012 = Chirikba, V. V. Rasselenie abkhazov v Turtsii. Chachkhalia, D. K. (peatoim). Dzhigetskii sbornik I. Voprosy etno-kul'turnoi istorii Zapadnoi Abkhazii ili Dzhigetii. Moskva: AKVA-Abaza, lk 22-96.

Veinberg 1901 = Veinberg, L. 1901. Khoven, baron fon-der, Khristofor Khristoforovich. Polovtsev, Aleksandr Aleksandrovich (toim). Russkii biograficheskii slovar'. Tom XXI. Faber-Tsiavlovskii. SPb: Tip. V. Bezobrazova i Ko, lk 381-382.

Vereštšagin, Arseni 1874 = Vereshchagin, A. V. 1874. Putevye zametki po Chernomorskomu okrugu. Moskva: Izdanie N. N. Mamontova.

Vojennaja... 1912 = Voennaia entsiklopediia. Tom 8. Gimry - Dvigateli sudovye. SPb.: T-vo I. Sytina, lk 438-439.

Volkova, Natalja 1974 = Volkova, N. G. 1974. Etnicheskii sostav naseleniia Severnogo Kavkaza v XVIII - nachale XX veka. Moskva: Nauka.

Wendland, Folkwart 1986. Zur Biographie von Pallas. Pallas, Peter Simon. Über die Beschaffenheit der Gebirge und die Veränderungen der Erdkugel (1777). Leipzig: Akademische Verlagsgesellschaft Geest \& Portig K.-G, lk 8-19.

Wunk, M. J. 1914. Mälestused Suhumist. Postimees nr 108, 14. mai, lk 7. 


\title{
Summary
}

\section{Small Abkhazia's big border issues: Baltic German explorers' contribution to ethnic argumentation}

\author{
Aivar Jürgenson \\ Senior Research Fellow \\ Institute of History, Archaeology, and Art History, School of Humanities, \\ Tallinn University \\ aivarj@tlu.ee
}

Keywords: Abkhazia, Baltic German explorers, border disputes, Caucasian War, colonization

The article examines Baltic German research expeditions to the north-western Caucasus, including Abkhazia, in the late 18th and early 19th centuries, and analyses the results of these trips. Although some of these researchers, such as Peter Simon Pallas and Heinrich Klaproth, came from Germany, most of the researchers were from the Baltic provinces of the Russian tsarist state: Johann Anton Güldenstädt, Otto Moritz Ludwig von Engelhardt, Johann Jacob Friedrich Wilhelm Parrot, and Theodor von Tornau. The main focus of the article is on the descriptions of the north-western region of Abkhazia, where the historical region Dzhigetia or Small Abkhazia is located, and which was inhabited by the Dzhiget ethnic group until the 1860s. Using data from Baltic German authors, especially Theodor von Tornau, an attempt is made to answer the question of whether or not Dzhigetians belonged to the Abkhazians. The article provides an overview of the historical location and fate of Dzhigets in the 19th century.

In general, the descriptions of the peoples of the Caucasus provided by the authors of the late 18th and early 19th centuries are superficial and do not follow a uniform classification. Therefore, their interpretation offers different possibilities today. The examples of recent interpretations given in the article convince us that Russian and Abkhaz authors have interpreted earlier authors differently. The most comprehensive accounts of Dzhigetia come from Theodor von Tornau, and it can be argued that the Dzhigetians were an Abkhaz ethnic group.

The question of the affiliation of Dzhigets is important in today's border disputes between Abkhazia and Russia. In the last decade, Russia has made territorial claims to Abkhazia in the region of historic Dzhigetia. It is also declared among the Russian scientific community that Dzhigetia is not historically-ethnically within the borders of Abkhazia. However, Tornau's data refute these statements of Russian authors. The ethnicity of the peoples of the border areas would probably not solve today's border problems, but would give to the parties of the dispute symbolic capital and moral support to defend their positions. 
Aivar Jürgenson on Eesti etnoloog ja ajaloolane (PhD aastast 2003). Töötanud Eesti Rahva Muuseumis teaduri ja Teaduste Akadeemia Ajaloo Instituudis vanemteaduri ja osakonnajuhatajana, hetkel töötab Tallinna Ülikooli Humanitaarteaduste instituudis vanemteadurina. Peamised uurimisteemad on eesti diasporaakogukondade ajalugu ja tänapäev ning etnomükoloogia.

Aivar Jürgenson (born 1969) is an Estonian ethnologist and historian (PhD since 2003). He has worked as a researcher at the Estonian National Museum and as a senior researcher and head of department at the Institute of History of the Academy of Sciences. Currently he works as a senior researcher at the School of Humanities of Tallinn University. His main research topics are the history and present of Estonian diaspora communities and ethnomycology. aivarj@tlu.ee 